\title{
Steroid hormone receptors and dietary ligands: a selected review
}

\author{
Miriam N. Jacobs* and David F. V. Lewis \\ School of Biomedical and Life Sciences, University of Surrey, Guildford GU2 7XH, UK
}

\begin{abstract}
Members of the nuclear steroid hormone superfamily mediate essential physiological functions. Steroid hormone receptors (SHR) act directly on DNA, regulate the synthesis of their target genes and are usually activated by ligand binding. Both endogenous and exogenous compounds and their metabolites may act as activators of SHR and disruptors of endocrine, cellular and lipid homeostasis. The endogenous ligands are generally steroids such as $17 \beta$-oestradiol, androgens, progesterone and pregnenolone. The exogenous compounds are usually delivered through the diet and include non-steroidal ligands. Examples of such ligands include isoflavanoids or phytooestrogens, and food contaminants such as exogenous oestrogens from hormone-treated cattle, pesticides, polychlorinated biphenyls and plasticisers. Certain drugs are also ligands; so nuclear receptors are also important drug targets for intervention in disease processes. The present review summarises recent reports on ligand-activated SHR that describe the selective regulation of a tightly-controlled cross-talking network involving exchange of ligands, and the control of major classes of cytochrome P450 (CYP) isoforms which metabolise many bioactive exogenous compounds. Many CYP have broad substrate activity and appear to be integrated into a coordinated metabolic pathway, such that whilst some receptors are ligand specific, other sensors may have a broader specificity and low ligand affinity to monitor aggregate levels of inducers. They can then trigger production of metabolising enzymes to defend against possible toxic nutrients and xenobiotic compounds. The influence of dietary intakes of nutrients and nonnutrients on the human oestrogen receptors ( $\alpha$ and $\beta$ ), the aryl hydrocarbon receptor, the pregnane $\mathrm{X}$ receptor, the constitutive androstane receptor, and the peroxisome proliferator-activated receptors $(\alpha$ and $\gamma$ ), can be examined by utilising computer-generated molecular models of the ligand-receptor interaction, based on information generated from crystallographic data and sequence homology. In relation to experimental and observed data, molecular modelling can provide a scientifically sound perspective on the potential risk and benefits to human health from dietary exposure to hormone-mimicking chemicals, providing a useful tool in drug development and in a situation of considerable public concern.
\end{abstract}

\section{Steroid hormone receptors: Human oestrogen receptors: Ligand-receptor interaction: Endocrine disruption}

\section{Endocrine-disrupting chemicals}

Endocrine-disrupting chemicals (EDC) are substances that can cause adverse effects by interfering in some way with the body's hormonal or chemical messengers. Under the control of the central nervous system, hormones are secreted by the endocrine glands and exert control on other cells of the body. The endocrine system is complex, with many organs producing different hormones, contributing to a multifaceted feedback regulatory system that is deficient in the developing fetus and infant. EDC are differentiated from classical toxicants such as carcinogens, neurotoxicants and heavy metals, because they can interfere with normal blood hormone levels or the subsequent action of those hormones, but do not have a classical toxic effect. The effects can influence and disrupt the hormonal regulation and hormonal imprinting (in the fetus) of normal cell differentiation, growth, development, metabolism and reproduction throughout life. Endocrine disruption can occur at levels far lower than those of traditional concern to toxicologists. Sometimes high doses shut off effects that occur at low levels, and sometimes low and intermediate doses produce greater effects than those observed at high doses. Human populations are exposed to complex mixtures of

\footnotetext{
Abbreviations: AhR, aryl hydrocarbon receptor; CAR, constitutive androstane receptor; CYP, cytochrome P450; DDT, dichlorodiphenyltrichloroethane; EDC, endocrine-disrupting chemicals; ER, oestrogen receptor; LBD, ligand binding domain; PCB, polychlorinated biphenyls; PPAR, peroxisome proliferator-activated receptor; PXR, pregnane X receptor; SHR, steroid hormone receptor.

*Corresponding author: Miriam Jacobs, fax +44 1483 300374, email m.jacobs@ surrey.ac.uk
} 


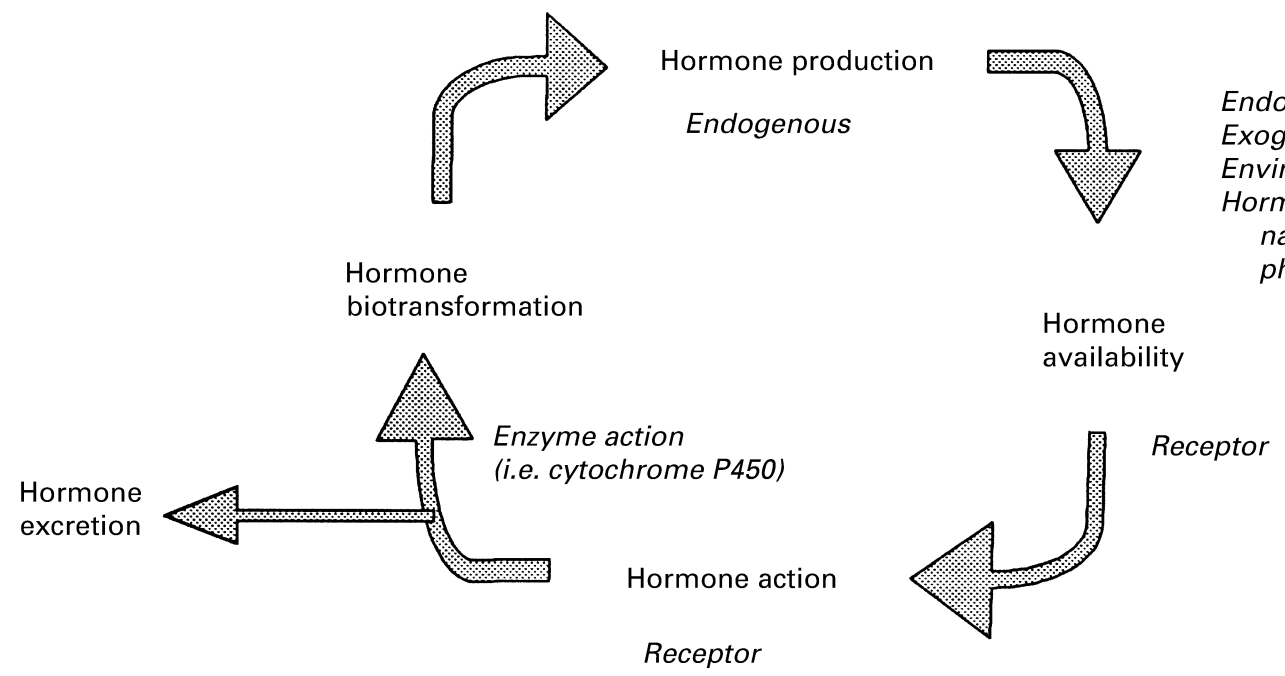

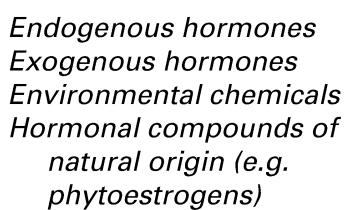
phytoestrogens)

Fig. 1. A simplified model of hormone dynamics. (From Crain et al. 2000.)

environmental and endogenous agents, which may act together or modulate one another to produce biological effects. While exogenous endocrine modulators can involve any hormonal system and be affected by normal physiological states (such as menstruation and menopause in women, the andropause in men, and puberty, the somatopause and adrenopause in both sexes), diet, stress and other lifestyle factors, the principal focus of the present review is on the effects of sex hormones, and especially oestrogenmediated effects, on the steroid hormone receptors (SHR) in human subjects where the ligands are delivered through the diet. The intention is that the present review will provide a basis for understanding some of the critical issues involved in hormone receptor-mediated toxicity, and the broad context involved.

\section{Hormone dynamics}

Accurate assessment of a chemical's potential to alter the endocrine system depends on consideration of the entire hormone dynamic pathway together with changes in hormone activity. Fig. 1 presents a simplistic model of hormone dynamics, following hormones from production to excretion.

After a hormone is produced, circulating and intracellular binding proteins regulate the hormones bioavailability. Then the hormone triggers action by binding to a specific cellular receptor. The hormone is then either excreted in the urine after conjugation reactions in the liver, or biotransformed into another hormone, which will begin the cycle of bioavailability, action and excretion or biotransformation.

Hormones, and hormone-mimicking chemicals, can potentially affect each point in the hormone dynamic cycle, and each point in the steroid hormone pathway, and the enzyme families associated with the pathway. Assessing the mode of action of an EDC is further complicated by many feedback mechanisms within and between the different hormone systems, as well as interconnections with the nervous and immune systems. Current scientific knowledge of these systems is fragmentary, but the emerging picture suggests an interlinked fabric of hormone dynamics where the delicately balanced compensatory systems are easily perturbed. Hormone dynamics have evolved over a long period of time to deal with hormone and dietary phytochemical exposure, but they are not a rapid response system able to deal effectively with the synthetic chemicals of the twentieth and twenty-first centuries.

At the molecular level, receptors mediate alterations of hormone availability, action, excretion and biotransformation, in concert with the cytochrome P450 (CYP) enzyme system. Many receptors have been identified and are awaiting the recognition of specific ligands and functions, and it is likely that more receptors will be discovered in the future. Each type of receptor has the potential to regulate a distinct endocrine signalling pathway, of which we only have a rudimentary knowledge.

\section{Hormone-mimicking chemicals and steroid hormone receptors}

In recent years there have been many reports on the increasing incidence of breast cancer in women (Davis et al. 1993, 1997; Bradlow et al. 1995, 1997; Davidson \& Yager, 1997) and decreased sperm counts and increasing incidence of testicular cancer in men (Sharpe \& Skakkebæk, 1993; Adami et al. 1994; Auger et al. 1995), together with adverse wildlife effects that include birth defects, reproductive failures, and sexual abnormalities (Colburn et al. 1993, 1999; Guillette \& MacLachlan, 1996). These conditions, related to oestrogen-like compounds, have stimulated research into both the chemical and molecular actions, and the clinical and epidemiological effects of a large variety of natural and synthetic oestrogens present in the environment (Falck et al. 1992; Hunter \& Kelsey, 1993; Wolff et al. 1993; Krieger et al. 1994; Stevens et al. 1994; Ahlborg et al. 1995; Wolff \& Toniolo, 1995; Gray et al. 1997; Hunter et al. 1997; Safe, 1997; Bernstein \& Press, 1998; Petreas et al. 1998; Krstevska-Konstantinova et al. 2001). The growing body of evidence on the hormone-like effects of many synthetic chemicals and by-products in fish, wildlife and man, has led to the instigation of endocrine-disruption screening programmes relating to persistent organic 
pollutants (for example, see National Institute of Environmental Health Sciences, National Institutes of Health, 2001; US Environmental Protection Agency, 2001), and the international persistent organic pollutants treaty signed in Stockholm, Sweden in May 2001 (United Nations Environment Programme, 2001).

\section{The biological differences in hormones and hormone metabolism}

In utero the natural sex hormones are largely responsible for development into females, or totally responsible for male development, as the default pathway for fetal development is phenotypically female. In the male fetus, androgens stabilise the Wolfian duct development in the fetus, and actively remove the Müllerian duct (the precursor to the female uterine system; Sharpe, 2001).

The most important factors guaranteeing the homeostasis of female and male sexual functions include differentiation and reproduction. Main target tissues include bone and skin, the cardiovascular system, the brain and central nervous and immune systems. Endocrine hormones are lipophilic (fatloving), moving easily through cell membranes to activate or suppress the nuclear receptors (i.e. receptors in the nucleus of the cell) that directly act on DNA. In synthesis with each other they contribute to the control of broad aspects of growth, development and adult organ physiology. The SHR family is extensive, but currently the emphasis is on a subclassification, the oestrogen receptors (ER; Colburn et al. 1993, 1999; Soto et al. 1995; Guillette \& McLachlan, 1996), with most effects attributable to pubertal or adult levels of steroids. Other members of the SHR family and other nuclear receptors of unknown functions (not discussed here) also play key roles in endocrine disruption (Parker, 1993). For example, EDC are known to affect the thyroid, adrenal glands and pancreas; a clear link between dichlorodiphenyltrichloroethane (DDT) and pancreatic cancer was recently reported (Porta et al. 1999), and the persistent DDT metabolite $1,1^{\prime}$-(dichloroethylidene)bis(4-chlorobenzene) has been shown to have anti-androgenic potential (Kelce et al. 1995). EDC such as phthalic acid and nonylphenol are now known to activate pregnane $\mathrm{X}$ receptor (PXR), both in vitro and in vivo, as observed for the ER, while bisphenol A has no effect on PXR-mediated transcription, but significantly enhances ER-mediated transcription (Masuyama et al. 2000).

\section{Molecular mechanics of endocrine action}

\section{Receptor-based mechanisms}

The nuclear receptor family have structural features in common. These features include a central highly-conserved DNA binding domain that targets the receptor to specific DNA sequences, termed hormone response elements. A terminal portion of this receptor $(\mathrm{COOH})$ includes the ligand binding domain (LBD) that interacts directly with the hormone. Embedded within the LBD is a hormonedependent transcriptional activation domain. The LBD acts as a molecular switch that recruits coactivator proteins and activates the transcription of target genes when flipped into the active conformation by hormone binding. The currentlyaccepted theory of steroid hormone binding suggests that in the absence of the hormone each receptor is associated with certain 'chaperone' proteins (these are other proteins which protect and aid the receptor; Weigel, 1996). Binding of the steroid hormone with the receptor protein causes a conformational change. This molecular switch results in the removal of the heat-shock complex and allows the receptors to dimerise. Then DNA binding to a hormone response element occurs, to produce a complex that can trigger or suppress the transcription of a selected set of genes (Fig. 2; Weigel, 1996; Alberts et al. 1997).

\section{Receptors interacting with enzymes}

The hormone receptors and chaperone cofactors also mediate hormonal homeostasis by the coordinated release and degradation of bioactive hormones. Steroid hormones, their metabolites, ingested plant and animal steroids and bioactive xenobiotic compounds are primarily metabolised by cytochrome P450 (CYP) enzyme reduction and oxidation in the liver. Many CYP have broad substrate activity and appear to be integrated into a coordinated metabolic pathway, such that whilst some receptors are ligand specific, other sensors may have a broader specificity and low ligand affinity. In this way they can monitor aggregate levels of inducers to trigger production of metabolising enzymes, and thereby mount a defence against toxic compounds in the diet. This hypothesis is strongly supported by the expression of a receptor-sensing system in the digestive tissue (Jones et al. 2000). CYP induction by EDC and other xenobiotics may therefore lead to alterations in endogenous regulatory pathways, with associated physiological consequences harmful to health.

\section{Most research is based on the oestrogen receptors}

Due to the early identification of $\mathrm{ER} \alpha$ and links between DDT and breast cancer, the ER have received most EDC research attention. So far they are known to exist as two subtypes, each one encoded by a separate gene. These subtypes are ER $\alpha$ (Brzozowski et al. 1997), and the recently discovered ER $\beta$ (Kuiper et al. 1998) and its isoforms, of which a spliced isoform, ER $\beta / 2$ appears to be equally expressed in tissue density studies (Petersen et al. 1998). The classical ER $\alpha$ subtype and ER $\beta$ receptors and isoforms apparently evolutionarily diverged over 450 million years ago (Kelley \& Thackray, 1999), suggesting that although they have evolved in parallel, this ancient duplication was to facilitate unique roles in vertebrate physiology and reproduction. The ER differ in tissue distribution and relative ligand-binding affinities (Kuiper et al. 1997; Petersen et al. 1998), which may help explain the selective action of oestrogens in different tissues (Gustafsson, 1999). This selectivity has important gender implications due to the differences in tissue physiology between women and men, and important disease implications, as different spliced variants are observed in malignant as opposed to normal tissues that lead to poor patient prognosis related to oestrogen refractoriness (Fujimoto et al. 2000). 


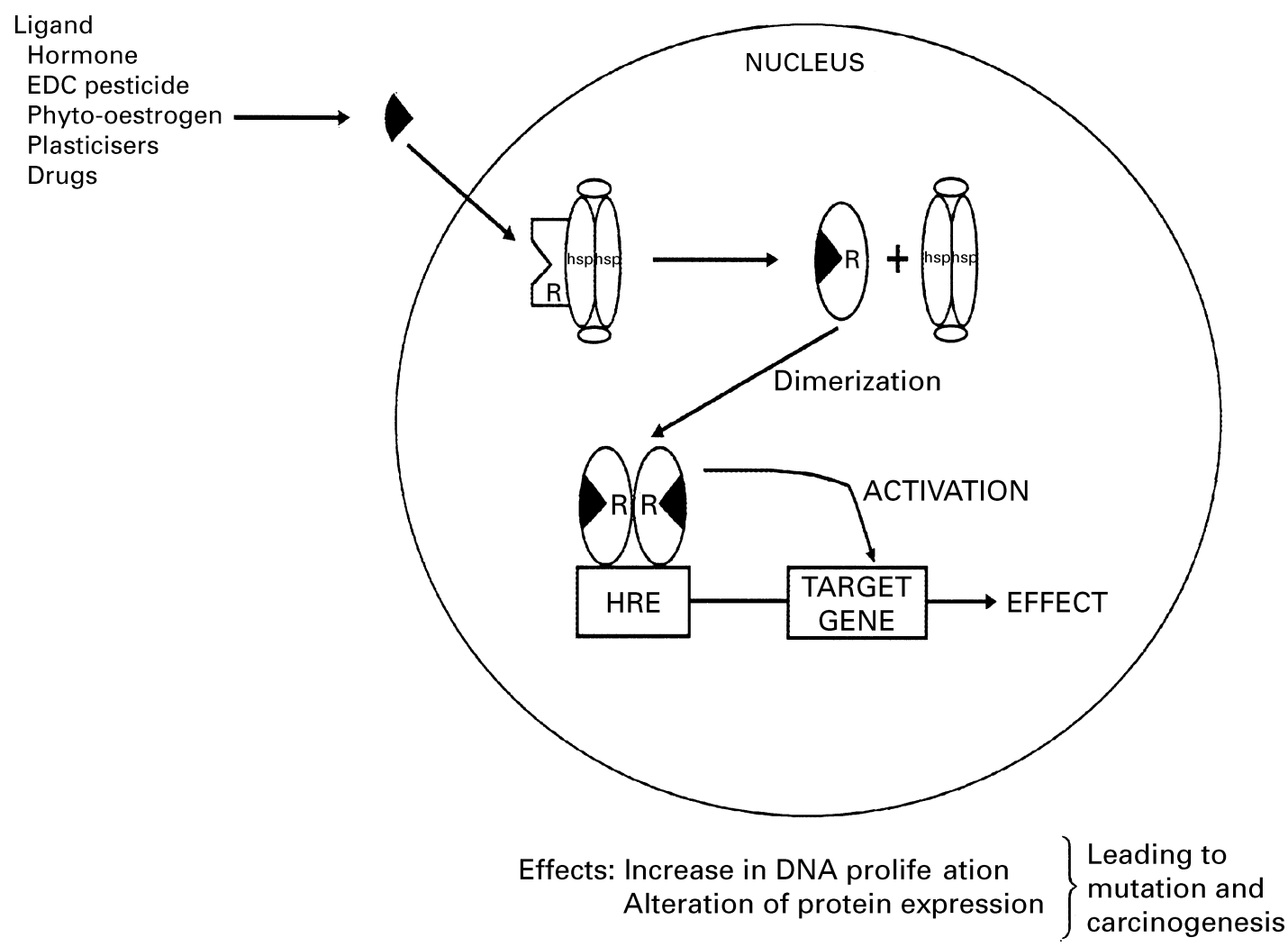

Fig. 2. Diagram showing the simplified mechanism of action of steroid hormone receptors. $R$, receptor (oestrogen receptors $\alpha$ and $\beta$, pregnane $X$ receptor, androgen receptor, constitutive androstane receptor and aryl hydrocarbon receptor); EDC, endocrine-disrupting compounds; hsp, heat-shock protein and cofactors 'chaperone complex'; HRE, hormone response element.

\section{Tissue differences in oestrogen receptor distribution in adults}

Whilst women have ER $\alpha$ and ER $\beta$ in breast, uterine and ovarian tissue, men have ER $\beta$ in the prostate and ER $\alpha$ in the testes, both women and men have ER $\alpha$ in the adrenals and kidneys, but ER $\beta$ in the brain, thymus, lung, vascular system, bladder and bone (Paech et al. 1997; Tetsuka et al. 1997; Kuiper et al. 1998; Warner et al. 1999). Fig. 3 shows the endogenous ligand $17 \beta$-oestradiol docked into the ligand-binding site of ER $\alpha$. ER $\alpha$ dominates specifically in the reproductive tissues, while ER $\beta$ plays an important role in the physiology of several tissues (see Fig. 4.) Female and male sex hormones can be understood to act as functional antagonists, such that an excess of oestrogenic hormones may depress male development or male functions. There are also situations in which female and male hormones may act synergistically (and, for example, show effects on bone density or the promotion of liver tumours). This complexity is the consequence of the multiple targets of these hormones within mammals, including target tissue other than the sex organs, as the tissue distribution of the ER in adults indicates.

\section{Serum oestradiol levels in prepubertal children}

Oestrogens are considered reversible cellular signals for adults, but when given to newborn mice at least one gene

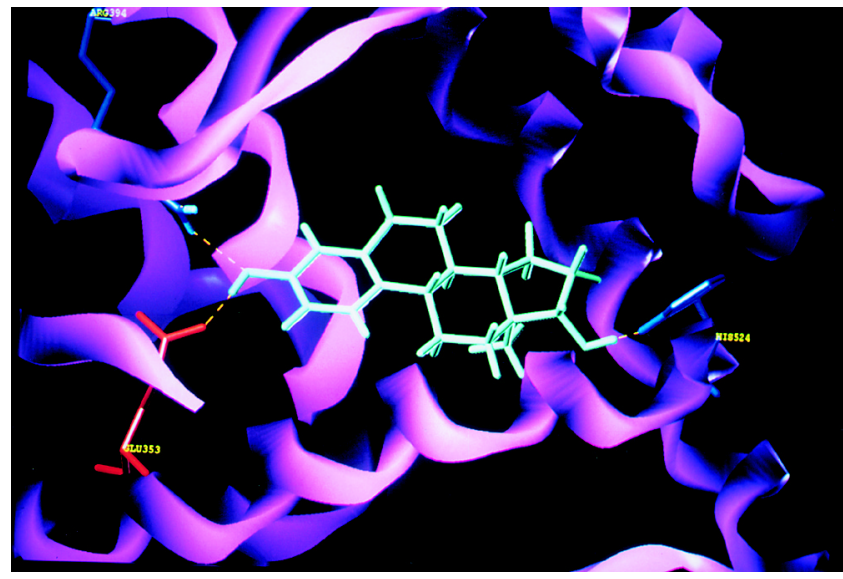

Fig. 3. A recent model of oestrogen receptor $\alpha$ with $17 \beta$-oestradiol docked in the ligand binding site, plotted from the crystal structure coordinates.

under oestrogen control is persistently expressed, even in the absence of oestrogen (Nelson et al. 1991, 1994). While very little is known about the role of hormones in gene imprinting, potent oestrogens have been observed in vivo to contribute to DNA methylation or demethylation (McLachlan et al. 2001). Low doses of oestrogen have been observed to have an important biological effect in girls with 


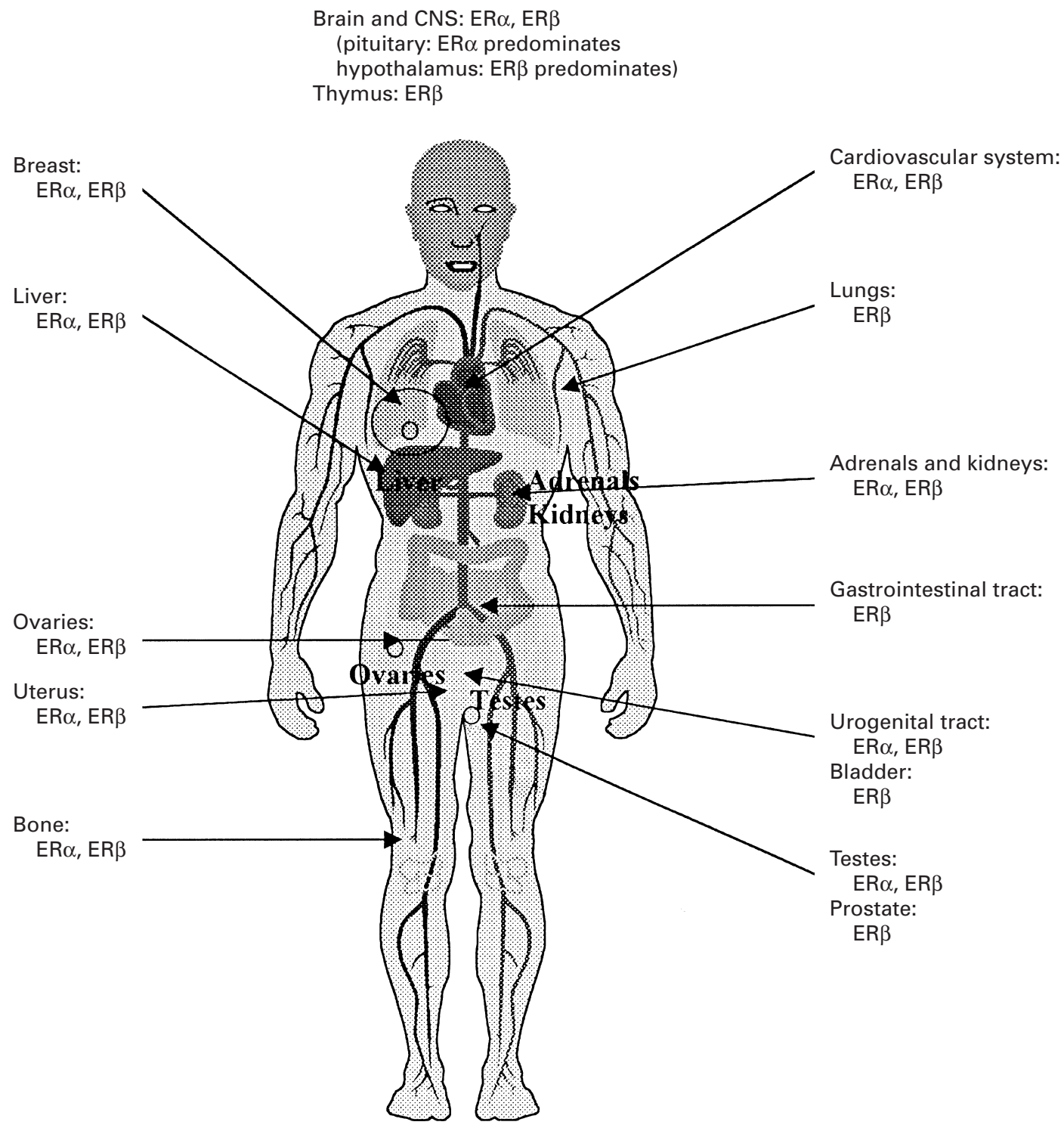

Fig. 4. Schematic diagram showing differences in tissue distribution of the oestrogen receptors (ER). CNS, central nervous system. (Adapted from Warner et al. 1999 and Gustafsson, 1999.)

Turner syndrome. A dose of $100 \mathrm{ng}$ ethinyloestradiol $/ \mathrm{kg}$ per $\mathrm{d}$ administered orally for 5 weeks resulted in a significantly increased growth velocity $(P<0 \cdot 001)$, with no effects on vaginal maturation or breast tissue. Higher doses did not increase the growth rate, indicating that oestrogen has a biphasic dose-response relationship for epiphyseal growth (Ross et al. 1983, 1986). Similar effects have been reported in boys, but there are clear gender differences in serum oestradiol levels prepubertally, with girls having approximately eight-fold higher oestradiol levels than boys (Klein et al. 1994). This difference may explain why girls mature faster than boys, but also, in a population exposed to excessive but low levels of oestrogen one may expect to see a slightly younger age for pubertal onset (Andersson \& Skakkebæk, 1999; Krstevska-Konstantinova et al. 2001) and an increase in oestrogen-related diseases and cancers (Newbold et al. 2001).

\section{Oestrogen receptors and the brain: relationships with neurodegenerative conditions}

The brain and the role of ER $\beta$ in the brain is attracting increasing interest. The expression of ER in the adult cortex and hippocampus, areas associated with learning and memory, have been observed experimentally to be responsive to neuronal injury, suggesting a link may exist between early onset of senile dementia or Alzheimer's disease in post-menopausal women with greatly reduced oestrogenic activity compared with normal post-menopausal levels (Shugrue \& Merchenthaler, 2000; Wise et al. 2001). During fetal and postnatal development peak neuronal cell proliferation occurs within specific brain regions, including the hippocampus and cortex. Unlike other organ systems, the brain and central nervous system development has a limited capacity to compensate for cell loss, and environ- 
mentally-induced cell death can lead to a permanent reduction in cell number. Combined with higher relative cerebral blood flow and the immaturity of the blood-brain barrier this factor can give rise to increased exposure of the brain to potential neurotoxins and EDC. The involvement of $E R \alpha$ and ER $\beta$ in the brain learning and memory centres suggest a logical mechanism of action of EDC in the brain that could trigger learning difficulties, as reported in male ER $\beta$-deficient mice (Ogawa et al. 1999; Gustafsson, 2000). Whilst this mechanism is speculation, in vivo work on ER-deficient and aromatase-deficient mice (Simpson et al. 2000) should shed more light on the mechanism of the disruption of ER and aromatase on brain function.

\section{Receptors and 'cross-talk'}

The receptors often have ligands in common (albeit with different binding affinities), and there is also a great deal of 'cross-talk' and 'ligand promiscuity'. In other words, the same chemical may be able to bind with different receptors, and, if they do, the binding strength may differ greatly between different receptors. This diversity can occur for endogenous hormones, exogenous hormones and environmental chemicals. For example, forms of the oestrogenic (oestradiol) and androgenic (androstanes) hormones are both ligands for ER $\beta$. Oestradiol is less potent for ER $\beta$ than for $E R \alpha$, whilst the natural ligands for ER $\beta$ may actually be androgens: $5 \alpha$-androstenediol and $3 \beta$-androstenediol (Gustaffson, 2000). The organochlorine pesticides transnonachlor and chlordane are known to activate both known $\mathrm{ER}$, and PXR, but with different affinities (Kuiper et al. 1997; Barkhem et al. 1998; Waxman, 1999; Jones et al. 2000). As these receptors are present in different ratios in different cell types and tissues, the response on a cellular, tissue and systemic level may be quantitatively very different, and may vary over time. Receptor modulation has been seen with lactation, when a form of ER $\beta$ has been observed to increase in the rat mammary glands (Gaido et al. 1999; Gustaffson, 2000) and in breast tissue hyperplasias, where a frequent mutation in the ER $\alpha$ gene shows increased sensitivity to oestrogen compared with wild-type ER $\alpha$, by affecting the border of the hinge and hormone binding domains (Fuqua et al. 2000).

EDC may act on some of, but not all, the receptors and their isoforms in the tissues of these organs, or act to different affinities, as many phyto-oestrogens (e.g. coumestrol and genistein), synthetic chemicals such as bisphenol A (Matthews et al. 2001) and organochlorine pesticides (e.g. methoxychlor and its analogue DDT) do for $\operatorname{ER} \alpha$ and ER $\beta$ (Table 1). More specifically, ER $\beta$ is dependent on pure agonists for the activation of transcription from its target promotors, while ER $\alpha$ can be activated by agonists, partial agonists (such as tamoxifen, which is used in the treatment of ER-positive breast cancer) and ligand-independent mechanisms. Appropriate test systems must be strategically designed to cover such multiple actions and interactions.

There is also evidence that isoforms of different receptors modulate each other at a functional level attempting to retain a balance. The modulation is aided at low (Hall \& McDonnell, 1999) and high hormone levels (Petersen et al.
Table 1. Relative binding affinities $(R B A)^{*}$ of suspected endocrine disrupters for oestrogen receptors (ER) $\alpha$ and $\beta$, adapted from solid-phase competition experiments (Kuiper et al. 1997)

\begin{tabular}{lcc}
\hline & \multicolumn{2}{c}{ RBA } \\
\cline { 2 - 3 } Compound & ER $\alpha$ & ER $\beta$ \\
\hline 17ß-Oestradiol & 100 & 100 \\
Isoflavones: & & \\
Coumestrol & 20 & 140 \\
Genistein & 4 & 87 \\
Daidzein & 0.1 & 0.5 \\
Pesticides: & & \\
O, $p^{\prime}$-DDT & 0.01 & 0.02 \\
Chlordecone & 0.06 & $<0.01$ \\
Endosulphan & $<0.01$ & $<0.01$ \\
Methoxychlort & $<0.01$ & \\
\hline
\end{tabular}

DDT, dichlorodiphenyltrichloroethane.

${ }^{*}$ Calculated as concentrations of oestradiol : competitor required to reduce the specific radioligand binding by $50 \%$. RBA value for oestradiol was arbitrarily set at 100 .

†The metabolite of methoxychlor, 2,2-bis-( $p$-hydroxyphenyl)-1,1,1-trichloroethane is approximately 100 -fold more active at $\mathrm{ER} \alpha$ than methoxychlor (Gaido et al. 1999).

1998) by different ER $\beta$ isoforms; this factor may enable a tissue to govern its own responsiveness to oestradiol, oestradiol metabolites and related hormones such as progestins, and oestrogen mimics or EDC. This speculation is supported by what appears to be an emerging pattern in nuclear receptor signalling, as similar balancing acts have been observed also in the $\alpha$ and $\beta$ forms of the human glucocorticoid receptor and the progesterone receptor.

\section{Disease scenarios: how much inhibition, how much activation?}

The proliferative role of ER $\alpha$ in breast cancer is well established, but there is increasing evidence that ER $\beta$ is part of the disease picture, through anti-proliferative activity, which has therapeutic implications. The distinct differences in activational mechanisms between the different ER and their isoforms will have a direct effect on possible disease scenarios such as ER-positive and ER-negative breast cancers, testicular and prostate cancers, and perhaps also brain injury.

These differences between the two isoforms are of great importance with respect to the endocrine-disrupting ability of a ligand. The ability of ER $\beta$ to function both as an inhibitor or activator depending on the agonist concentration suggests that totally different patterns of gene expression may be observed at different hormone levels, and may be a mechanism by which cellular sensitivity to hormones is controlled.

In tissues where ER $\alpha$ and $E R \beta$ co-localise, fluctuations in the bioavailability of receptor-activating ligands may have a greater impact, so characterising the interactions of EDC with both ER $\alpha$ and ER $\beta$. There can also be additional nonhormonal pathways influenced by specific compounds. A substance may act in a synergistic way on one target and in an antagonistic way on another one (Paech et al. 1997). Such opposing effects may also occur at different dose levels of the same substance, or as combinations of, for 
example, phyto-oestrogens and polychlorinated biphenyls (PCB; Jacobs et al. 1999), and other EDC (Payne et al. 2001), but experimentally there have been difficulties replicating these findings, and consequently one study has been retracted (Arnold et al. 1996, 1997; McLachlan, 1997). The in vitro evidence of additive potency of combined EDC pesticides for $\mathrm{ER} \alpha$ is far stronger (Ramamoorthy et al. 1997; Payne et al. 2001).

Phyto-oestrogens appear to have a greater affinity for ER $\beta$ than ER $\alpha$ (Kuiper et al. 1997), but they have an ER $\alpha$ selective efficacy (Gustaffson, 2000), while EDC such as the hydroxylated metabolites of methoxychlor appear to be an ER $\alpha$-specific agonist, and ER $\beta$ antagonist (Gaido et al. 1999), but with about the same affinity for both isoforms (Kuiper et al. 1997).

\section{Oestrogen receptor $\beta$ and men}

Perinatal exposure of the male fetus to potent oestrogens is known to increase the incidence of cryptochordism and hypospadias at birth, and the incidence of small testes, reduced sperm counts, epididymal cysts, prostatic abnormalities and testicular cancer in adult animals. ER $\beta$ appears to be preferentially expressed in spermatocytes at various developmental stages in the testes, specifically the gonocytes, spermatogonia and spermatocytes. This finding suggests that EDC with an affinity for ER $\beta$ may find their way into precursors of sperm and cause disturbances in their function, disrupting male reproductive functions (Giwercman et al. 1993; Hess et al. 1997; Sharpe, 1997; Sharpe et al. 1998; Ebling et al. 2000; Shugrue \& Merchenthaler, 2000).

Timing is all-important. During fetal testicular development, if one phase of development is out of phase with the following step (such as Müllerian duct regression), developmental problems ensue in the adult that may not become apparent until later developmental stages, such as puberty, have been completed. This type of problem is reflected particularly in the reports of falling sperm counts (Auger et al. 1995) incidence of testicular cancer (Adami et al. 1994) and decreased fertilization rates in couples with paternal pesticide exposure (Tielemans et al. 1999). Coupled with the likelihood that the endogenous ligand for ER $\beta$ is probably not oestradiol, but is an androgenic metabolite, investigation of the androgenic interactions with ER $\beta$ is critical in understanding the increasing adverse reproductive effects seen in men in relation to dietary exposure to hormonally-active compounds.

ER $\beta$ is also reported to play a central role in oestrogen signalling in normal and malignant prostate epithelial cells (Lau et al. 2000). While the roles played by oestrogens in the transformation from a healthy prostate cell to a cancerous one remain controversial, the role of androgens in this transformation is clearer. Peroxisome proliferatoractivated receptor $\alpha(\operatorname{PPAR} \alpha)$ also has a role, it is functionally present in human prostate, but is down regulated by androgens and over-expressed in advanced prostate cancer (Collett et al. 2000).

\section{The many biological roles of oestrogen receptor $\beta$}

Data addressing the various biological roles of ER $\beta$ are being generated from in vivo studies, by developing mice with a deleted ER $\beta$ gene (Gustafsson, 1999). These ER $\beta$ knockout (BERKO) mice display reduced fertility in the female, and show the essentiality of ER $\beta$ for normal functioning ovaries. At the beginning of the oestrus cycle in particular, ER $\beta$ expression is high, but after the luteinizing hormone surge, ER $\beta$ is rapidly down regulated; ER $\alpha$ : ER $\beta$ in the ovary is about 1:9. Another phenotypic characteristic of BERKO animals of both sexes is that the bladder epithelium, the epithelium of the dorsal prostate, the coagulation glands and the urethra show signs of hyperproliferation, suggesting that the growth control of these tissues is impaired if ER $\beta$ levels are compromised, and that ER $\beta$ may have a protective role against hyperproliferation and carcinogenesis. For both male and female BERKO mice reproductive behaviour appears normal, although the males appear to be more aggressive under certain conditions (compared with wild-type mice).

Kuiper, Gustafsson and coworkers (Ogawa et al. 1999; Gustafsson, 2000) are continuing to investigate the phenotypic characteristics of BERKO animals with particular reference to the cardiovascular system, bone, the immune system, sexually-differentiated liver metabolism and reproductive and non-reproductive behaviour. Research into defects in ER $\beta$ expression and activity should also yield useful data for disease syndromes involving excess androgens in women, particularly as seen in women with polycystic ovarian syndrome, with symptoms such as secondary male characteristics, menstrual disruption and difficulty conceiving (Franks et al. 1999).

\section{Oestrogen receptor $\beta$ and ovarian cancer}

Steroid hormone expression in ovarian surface epithelial cells (the tissue of origin for $>90 \%$ of ovarian cancers) has been observed to be disrupted in ovarian cancer cells taken from post-menopausal women (Lau et al. 1999). In the cancerous cells the normal healthy co-expression of ER $\alpha$ and ER $\beta$ mRNA (along with other receptors) were disrupted, with an ensuing loss of $\mathrm{ER} \alpha$, progesterone receptor and androgen receptor mRNA, suggesting that these receptors may be responsible for the neoplastic transformation of this cell type, but not ER $\beta$, whose mRNA levels appear to be unaffected by this malignant state. Lau et al. (1999) also suggest that ER $\beta$ action may depend on functional ER $\alpha$ levels. Taken together, these findings implicate the regulation of normal ovarian cells by oestrogens, androgens and progestins. The emergence of sex hormone resistance, via down-regulation or mutational inactivation of receptors (including the receptors ER, androgen receptor, constitutive androstane receptor (CAR) and PXR described later (p. 113) may be a key feature of ovarian epithelial transformation, which may lead to diseases such as endometriosis, some cases of sterility and uterine or ovarian cancers. 
Dietary exposure: synthetic oestrogens $v$. phyto-oestrogens

Phyto-oestrogens are found in the diet, and are widely available from plant foods, including $\mathrm{N}$-fixing plants and legumes such as clover (Trifolium spp.), lentils (Lens culinaris) and soyabeans, grains such as rye, lignans such as those found in linseed, and hops (Humulus lupulus L.) (Milligan et al. 1999; Cassidy \& Faughnan, 2000; H Adlercreutz, unpublished results). They do not rapidly accumulate and are water soluble. They are readily excreted in urine $(6-8 \mathrm{~h})$, and they are probably the source of greatest dietary exposure to environmentally-derived oestrogen mimics. On one hand, they can be regarded as a defence mechanism for the plant to reproductively impair herbivore and omnivore endocrine systems, and thus be an effective strategy to reduce local herbivore populations, as first noted in the 1950s when Australian clover was found to be the feminising agent responsible for impairing sexual performance in rams, with a dramatic effect in lambing (Bradbury \& White, 1954). However, scientific evidence indicates that counterdefences have evolved such that adult diets rich in phyto-oestrogens are associated with a reduced incidence of cardiovascular disease, breast cancer, prostate cancer and osteoporosis. Asian women and vegetarians have a lower than average breast cancer risk, together with a relatively higher excretion of urinary phyto-oestrogens (Cassidy, 1996; Adlercreutz, 1998, Bingham et al. 1998; Cassidy \& Milligan, 1998; Cassidy \& Faughnan, 2000; H Adlercreutz, unpublished results).

Some of the possible SHR mechanisms of action of EDC and phyto-oestrogens such as genistein are structure specific (Fig. 5(a)), but others combine with structurally-diverse ligands, e.g. PCB 153 (Fig. 5(a and b)) and DDT (Fig. 5(c)). When the structures of many phyto-oestrogen compounds are overlaid with the oestrogen structure, they can be virtually superimposed, the distance between the hydroxyl groups at each end of the molecules are almost identical. These distances determine hydrogen bond interaction. The more structurally-diverse synthetic compounds have far greater flexibility so they can move to, bind with and activate a wider range of receptors.

Synthetic hormone mimics, such as PCB, dioxins, brominated flame retardants and organochlorine pesticides, accumulate within the food chain and, due to their fat solubility and long half-lives, persist and bioaccumulate in adipose tissue and bone for many years, unlike phytooestrogens. DDT, for example, has a half-life of 10 years. While dietary intakes represent far smaller doses compared with phyto-oestrogen intakes, they remain available as ligands to the SHR system for a far longer period of time, and the metabolised forms, particularly when hydroxylated, have greater affinity for the ER (Jacobs 1998; Meerts et al. 2001). The ubiquitous EDC represent potential risk factors for a number of human cancers and other detrimental health effects. They are present at detectable levels in food and water, even those such as DDT which have been banned in many countries. PCB, DDT metabolites, dioxins and brominated flame retardants are the predominant persistent organic pollutants of concern in fatty animal-based foods such as oily fish, fish oils, meat and dairy products (Jacobs et al. 2000, 2001a,b; Liem et al. 2000).
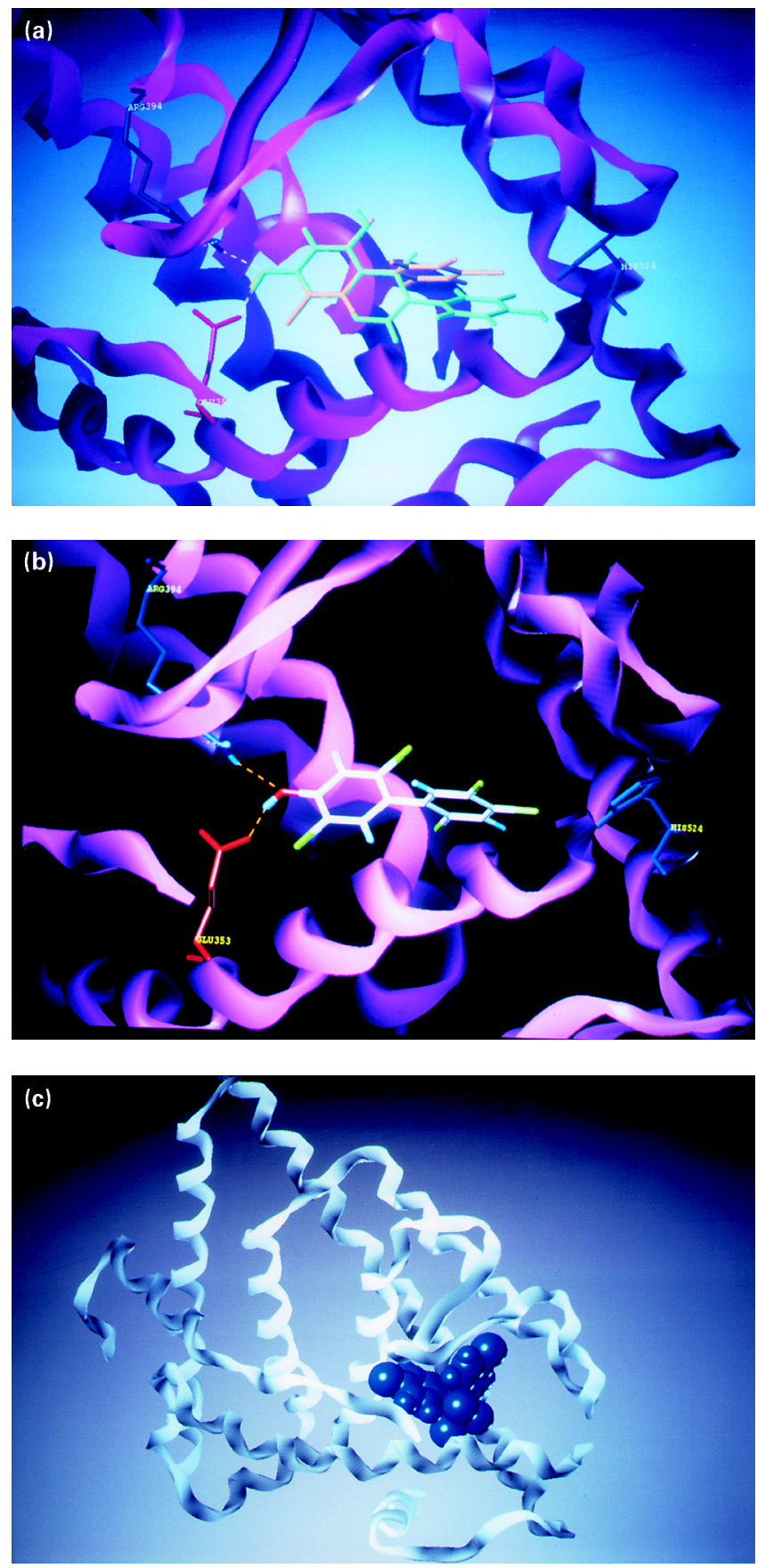

Fig. 5. Molecular homology models of oestrogen receptor $\alpha$ with (a) genistein (in green) and hydroxy polychlorinated biphenyl (PCB) (in pink), (b) hydroxy PCB 153 and (c) dichlorodiphenyltrichloroethane (space-filled) in the ligand binding site.

Phyto-oestrogens may influence carcinogenesis via their hormonal, anti-hormonal and antioxidant actions in a beneficial way, when administered throughout life. Substantial evidence indicates that diets high in plant-based foods may explain epidemiological variance of many hormonedependent diseases that are major causes of mortality and morbidity in Western populations. Phyto-oestrogens such as genistein (from soyabean) have been shown to stimulate cell 
proliferation and bind to ER at relatively low levels (i.e. a low affinity) both in vitro (Cassidy, 1996; Bingham et al. 1998; Cassidy \& Milligan 1998; Jacobs et al. 1999) and in vivo (Milligan et al. 1998), and have been reported to have a protective effect if given before puberty (Lamartinière et al. 1995) and an inhibitive effect on the growth of cancerous prostate cells (Hillman et al. 2001), but a detrimental effect, with increased risk of uterine cancer, if given in infancy (Newbold et al. 2001).

EDC pesticides have a more flexible molecular structure compared with phyto-oestrogens, and thus greater affinity for the cellular receptors. It is frequently argued in the literature that the EDC pesticides bind very weakly to the ER compared with natural oestrogens and some phytooestrogens (Safe, 1995, 1997; Safe et al. 1997). Quantitative structure-activity relationship studies have revealed more fully the importance of understanding differences in ligand binding within the ER (Jacobs, 1998; Jacobs \& Lewis, 1999), and these differences need to be related to differences in serum levels of hormones at all stages of human development. The binding affinity of EDC pesticides for the classical ER (ER $\alpha)$ differs markedly from those of ER $\beta$ and other receptors (e.g. PXR), and there are additional modes of action taking place. For example, organochlorine pesticides such as $o, p^{\prime}$-DDT and alachlor have been reported to partially mimic oestradiol and function to suppress apoptosis (programmed cell death) in ER-responsive cells. Apoptosis appears to play a critical role in the generation and progression of cancer, and is probably regulated by steroid hormones in hormone-responsive tissues (Burow et al. 1999). p, $p^{\prime}$-DDT has been found to be capable of activating cellular signalling events in ER-negative breast cancer cells (Shen \& Novak, 1997a,b), and thus it is highly likely that some organochlorine pesticides may function through other signalling pathways.

Chronic exposure to large quantities of phyto-oestrogens in foods might have a direct binding effect on the ER and other hormone receptors. Indeed, coumestrol, a very potent phyto-oestrogen, has uterotropic activity in the immature rat that is typical of the activity of the endogenous oestradiol (Ashby et al. 1999). Newbold et al. (2001) report that in vivo genistein exposure in newborn mice, a time at which the developing organism would normally be using natural oestrogen signals to guide development, increase the risks of uterine cancer in adult life. The amount of genistein used by Newbold et al. (2001) was slightly higher than the amount consumed by infants, but was within one order of magnitude of the level of human exposure (approximately $27 \mathrm{mg}$ genistein/d for infants feeding on formula $v .50 \mathrm{mg} / \mathrm{d}$ in the experiment). Outbred female CD-1 mice were treated at age $1-5 \mathrm{~d}$ with equivalent oestrogenic doses of diethylstilbestrol $(0.001 \mathrm{mg} / \mathrm{kg}$ per d) or genistein $(50 \mathrm{mg} / \mathrm{kg}$ per d). At 18 months the incidence of uterine adenocarcinoma was $35 \%$ for genistein and $31 \%$ for diethylstilbestrol. These data suggest that genistein is carcinogenic if exposure occurs during critical periods of differentiation. Other impacts observed from genistein exposure included reductions in fertility during adulthood following exposure as a newborn.

Inappropriate oestrogens can alter development by changing the intensity of the oestrogen signal, whether they are from natural sources or synthetic sources. In the adult such an intake may also have indirect modulating effects on associated and related factors (e.g. chaperone heat-shock proteins), such that even whilst acting as an oestrogen at certain doses, phyto-oestrogens such as genistein may also be acting on multiple sites, having indirect anti-oestrogenic and anti-cancer effects.

An important but neglected dietary intake avenue of oestrogens occurs in hormone residues from meat treated with sex steroids for growth promotion (Andersson \& Skakkebæk, 1999). While the Food and Agriculture Organization/World Health Organization (1998a,b) expert committee on food additives and the US Food and Drug Administration (1999) consider that the residues found in meat from treated animals are safe for consumers, they have not considered the sensitivity of healthy prepubertal children to low levels of oestradiol (Andersson \& Skakkebæk, 1999) or oestrogen-mimicking compounds (Howdeshell et al. 1999), and pre- and postnatal infants to gene imprinting (McLachlan et al. 2001) from this dietary source of oestrogens. Possible adverse effects on human health by consumption of meat from hormone-treated animals cannot be excluded.

\section{Key nuclear receptors: a multifaceted communication system}

Members of the same nuclear receptor family share a common heterodimerization partner, retinoid $\mathrm{X}$ receptor (9cis-retinoic acid receptor; RXR), and there is cross-talk with other nuclear receptors and with a broad range of intracellular signalling pathways. There may be competition with retinoid $\mathrm{X}$ receptor for the dimerization stage of receptor activation of DNA. There may even be a cascade effect, where metabolites produced through the activities of one receptor are specific signalling molecules (and ligands) to modulate the next receptor, a link in the nuclear receptor intercommunication web of the body (Fig. 6).

To demonstrate how important it is to consider the spectrum of receptors when assessing the dietary input of endocrine disrupters, a brief description will be given of selected receptors and their known interactions with ER. The interactions are far more complex than the brief descriptions may imply.

\section{Aryl hydrocarbon receptor}

The aryl hydrocarbon receptor (AhR), a member of the PerArnt-Sim family of nuclear regulatory basic helix-loophelix proteins, has been detected in nearly all vertebrate groups examined (Hahn, 1998) and appears to have a fundamental role in cellular physiology, neurodevelopment and circadian rhythmicity (Poellinger, 2000). Predominantly found in hepatocytes, but also in breast cancer cells (Nguyen et al. 1999), AhR regulates the expression of a number of genes, including CYP 1A1, 1A2 and 1B1 and glutathione $\mathrm{S}$-transferase $\mathrm{M}$ in a ligand-dependent manner. AhR is also up regulated during cell division. Exposure to 2,3,7,8-tetrachlorodibenzo- $p$-dioxin, the most potent AhR ligand known, results in a wide variety of species- and tissue-specific toxic and biological responses. Animals treated with 2,3,7,8-tetra- 


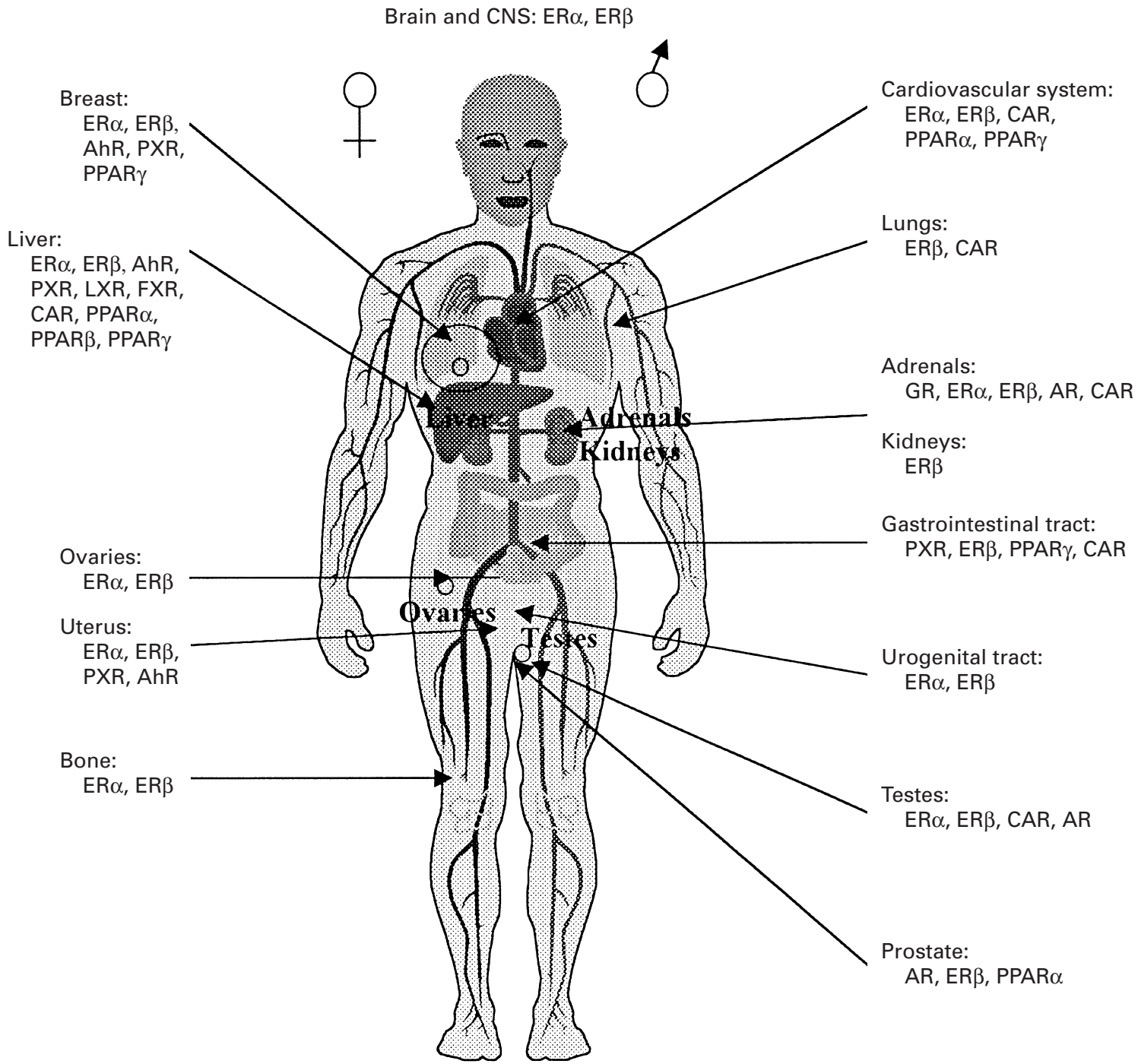

Fig. 6. Schematic diagram showing gender differences in tissue distribution of steroid hormone receptors. ER, oestrogen receptor; AhR, aryl hydrocarbon receptor; PXR, pregnane $X$ receptor; PPAR, peroxisome proliferator-activated receptor; $L X R$, liver $X$ receptor; FXR, farnesoid $X$ receptor; CAR, constitutive androstane receptor; GR, glucocorticoid receptor; $A R$, androgen receptor.

chlorodibenzo-p-dioxin have developed abnormalities in several organs, including the thyroid, thymus, lung and liver, and in immune and endocrine functions. Wasting and lethality, and induction of gene expression have also been shown to be AhR dependent (Abbot et al. 1999; Diliberto et al. 2000).

Within the cytosol of the cell AhR is associated with a heterodimeric transporter protein partner, termed the AhR nuclear transporter protein. The unliganded AhR may also act through other mechanisms by being phosphorylated to key regulatory proteins such as heat-shock protein 90 , which appears to be required for maintaining the receptor in a nonactivated ligand-binding conformation (Pongratz et al. 1992, cited in Poellinger, 2000), as is the case with the ER, and other proteins such as $\mathrm{p} 37$, AIP, XAP2, src, rel and $R b$ (Birnbaum, 2000). AhR-knockout mice display reduced fertility, reduced viability, and liver and immune deficits (Diliberto et al. 2000) in some independently-generated-line mice, but not others (for review, see Poellinger 2000).
The best characterised high-affinity ligands for the AhR include a variety of ubiquitous manmade toxic and hydrophobic chemicals, including halogenated aromatic hydrocarbons, such as the polychlorinated dibenzo- $p$ dioxins, dibenzofurans and biphenyls, and polycyclic aromatic hydrocarbons such as benzo $(a)$ pyrene, 3-methylcholanthrene and benzoflavones, and other chemicals. Certain dietary indole derivatives, such as indolo[3,2$b]$ carbazole appear to bind with the same affinity to that of 2,3,7,8-tetrachlorodibenzo- $p$-dioxin (Gillner et al. 1993), but a physiological receptor ligand has not been identified yet. Weaker ligands include diaminotoluene, omeprazole, brevetoxin, indole carbinols (found in cruciferous vegetables) and endogenous weak ligands such as bilirubin (a hydrophobic haem degradation product metabolised in the liver), biliverdin (Sinal \& Bend, 1997; Phelan et al. 1998) and water-soluble metabolites of tryptophan, tryptamine and indole acetic acid (Heath-Pagliuso et al. 1998), as well as equol, indicating the wide gamut of structural 
diversity of AhR ligands. Quantitative structure-activity relationship studies of compound properties without the AhR model (Lewis \& Jacobs, 1999) have been observed to concur with the AhR model (MN Jacobs and DFV Lewis, unpublished results).

Many of these ligands activate other receptors; dioxins, for example, have anti-oestrogenic activity in the ER, while equol is strongly oestrogenic. The endogenous ligands hint further at the developmental role of AhR, as persistent CYP1A1 and CYP1A2 gene expression has been observed in congenitally-jaundiced Gunn rats (Lorenzen \& Kennedy, 1993, cited in Phelan et al. 1998). Both enzymes play a role in the oxidative metabolism of bilirubin, decreasing its toxicity and enhancing its elimination, an important detoxication role in the newborn infant where jaundice commonly occurs due to less-developed liver function and excretion.

\section{Pregnane X receptor}

An important requirement for homeostasis is the detoxication and removal of endogenous hormones and xenobiotic compounds with biological activity. PXR (Blumberg et al. 1998; Kliewer et al. 1998; Lehmann et al. 1998), is involved in activating the expression of several CYP detoxifying enzymes, including CYP3A4 in the adult and CYP3A7 in the fetus, in response to xenobiotics and steroids (Pascussi et al. 1999). CYP3A4 is the major human hepatic CYP, and has been suggested to be involved in the metabolism of $>60 \%$ of drugs in clinical use (Maurel, 1996). PXR is highly divergent between species, with great differences in PXR activation profiles due to differences in the LBD (Jones et al. 2000).

The major site of PXR expression is in the liver cells and the gastrointestinal tissues, but they are also present in both normal and neoplastic breast tissue. Indeed, the level of PXR in tumours where ER was present was significantly lower $(P=0.04)$ than that in tumours where ER was absent (Dotzlaw et al. 1999). PXR can be activated by a variety of chemically-distinct ligands, in a species-dependent manner, including endogenous hormones such as oestrogen, pregnenolone (Fig. 7) and progesterone, their synthetic derivatives such as pregnenolone 16 $\alpha$-carbonitrile, bile acids and also organochlorine pesticides, phthalic acid and nonylphenol, rifampicin, dexamethasone, corticosterone, spironolactone, phenobarbital, cholecalciferol and ligands of plant origin such as hyperforin (Masuyama et al. 2000; Moore et al. 2000; MN Jacobs and A Woodrooffe, unpublished results), coumestrol and genistein (MN Jacobs and A Woodrooffe, unpublished results). Many of these compounds activate other receptors, from liver receptors such as LXR and FXR to the ER, AhR and vitamin $D$ receptor. The percentage inhibition in competitive binding assays for the pesticide trans-nonachlor is approximately 100 , with seven times greater activation than the activation by pregnenolone $16 \alpha$-carbonitrile in human PXR transfection assays (Jones et al. 2000). PXR is also essential in mediating transcriptional activation of $C Y P 3 A$ by environmental contaminants (Schuetz et al. 1998).

It appears that there is a specific regulatory pathway where the accumulation of steroidal PXR ligands, including xenobiotics, results in increased $C Y P 3 A$ transcription and

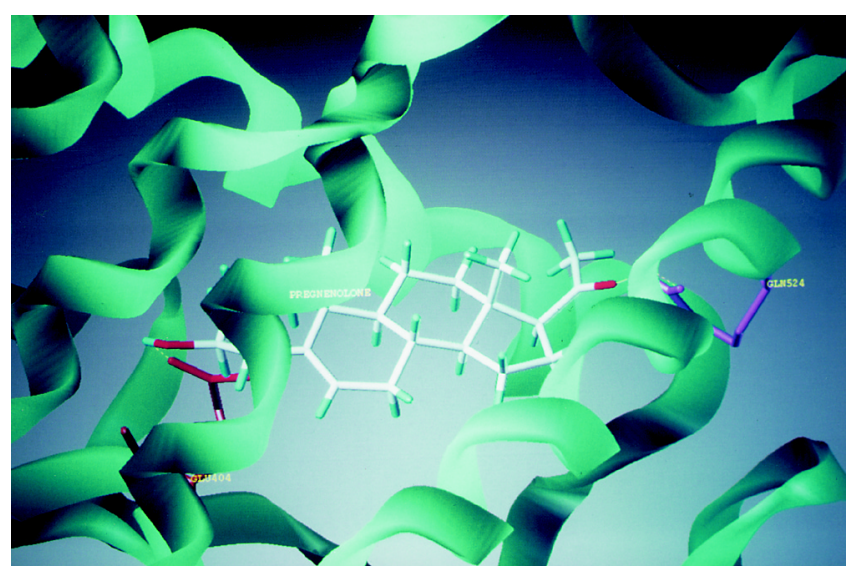

Fig. 7. Molecular homology model of the pregnane $X$ receptor with the endogenous ligand pregnenolone, occupying the ligand binding site.

steroid catabolism, possibly providing the route for excess steroids to be eliminated from the body. Thus, not only is PXR a xenobiotic sensor, it is also a key player in the regulation of steroid homeostasis (steroid metabolism) by involvement in the expression of steroid hydroxylases and detoxication (Kliewer et al. 1999). By implication, EDC affecting PXR may also have indirect effects on the regulation of steroid homeostasis.

Some SHR have quite different unanticipated mechanisms of action which EDC may also influence directly or indirectly, as is the case with CAR.

\section{The constitutive androstane receptor}

Present largely in the liver, CAR heterodimerises with retinoid X receptor (Baes et al. 1994; Choi et al. 1997) and interacts with, and is inhibited by, two endogenous steroids, androstanol and androstenol, via a mechanism that involves a widely-expressed nuclear receptor coactivator, SHR coactivator-1. Both PXR and CAR are involved in the expression of steroid hydroxylases, and consequently regulate key steps in steroid metabolism (Kliewer et al. 1999). Unlike most nuclear receptors, including PXR and $\mathrm{ER}$, ligand activation of CAR inhibits receptor-dependent gene transcription. CAR carries out this action through the ligand-independent recruitment of transcriptional coactivators. CAR functions in a manner opposite to that of the conventional nuclear receptor pathways.

The physiological relevance of CAR is unknown as yet, although piecemeal evidence is accumulating. There are sex differences in plasma androstane levels, and recently CAR has been implicated as a transcriptional regulator of the gene governing the steroid hydroxylase CYP2B (Forman et al. 1998; Honkakoski et al. 1998; Xie et al. 2000). The phenobarbital-responsive DNA elements reporter gene has been shown to be activated by CAR (Honkakoski et al. 1998). CAR is highly responsive to phenobarbital-type compounds, including certain $\mathrm{PCB}$, pesticides, drugs, solvents and other xenobiotics, such that endogenous $C Y P 2 B$ is responsive to phenobarbital and other inducers only in the presence of suppressed CAR. At the systemic level, hormonal imbalances that affect androstanol and 
androstenol levels may impart a perturbation at the molecular level, preventing or inducing the inhibition of CAR and consequently the steroid hydroxylase CYP2B.

\section{Human peroxisome proliferator-activated receptor}

The PPAR are a family of orphan receptors with fundamental roles in regulating energy balance (Johnson et al. 1997; Blumberg \& Evans, 1998; Uauy et al. 1999; Willson et al. 2000; Bar-Tana, 2001). A number of prevalent metabolic disorders such as obesity, atherosclerosis and type 2 diabetes are associated with a shift in this balance. The PPAR are activated by chemicals which elicit increases in the number and size of peroxisomes when administered to rodents (Kliewer et al. 1999).

Three closely-related PPAR, $\alpha, \beta / \delta$ and $\gamma$, are found in the liver, kidney, heart and haematopoietic and adipose tissues, but with different expression patterns. PPAR $\alpha$ is found in liver, kidney, heart and muscle, $P P A R \beta / \delta$ is expressed in nearly all tissues and PPAR $\gamma$ is expressed in fat cells, the large intestine and monocyte lineage cells (Memon et al. 2000). The individual PPAR each play key roles in lipid metabolism and homeostasis; they are responsible for CYP4A induction; peroxisomal enzyme induction and hepatic peroxisome proliferation. PPAR $\alpha$ has a central role in hepatogenesis, and PPAR $\gamma$ has a central regulatory role in adipogenesis (Willson et al. 2000). PPAR $\alpha$ regulates key steps in lipid and fibrate metabolism, and this receptor is the molecular target for naturally-occurring plant fatty acids (pristinic acid and phytanic acid) present at physiological concentrations (Zomer et al. 2000), long-chain polyunsaturated fatty acids, eicosanoids (Uauy et al. 1999), and peroxisome proliferators, which include drugs such as the fibrates (used widely to lower high triacylglycerol levels, a risk factor in CHD) and synthetic chemicals such as the phthalate ester plasticisers and pesticides (Kliewer et al. 1999). PPAR $\gamma$ ligands include fatty acids, prostaglandins and the anti-diabetic thiazolidinedione drugs (Memon et al. 2000; Willson et al. 2000). Pristinic acid and phytanic acid are branched-chain fatty acids obtained through the diet from the chlorophyll in plants. Present at micromolar concentrations in healthy individuals, they can accumulate in a variety of inherited disorders. Potent binding of pristinic acid and phytanic acid with PPAR $\alpha$ (Zomer et al. 2000) indicates a primary mechanism for metabolising these dietary fatty acids. The PPAR have a far larger ligand binding pocket than the receptors so far discussed, and there are differences in the shape of each PPAR ligand binding pocket (Jacobs et al. 2000), giving broad ligand specificity on a structural basis.

Another factor to be considered is modulation through cross-talk between PPAR and other nuclear receptors or signalling molecules. For example, thyroid hormone suppresses hepatic peroxisome proliferator responses and exhibits inhibitory cross-talk with PPAR $\alpha$, due in part to competition between the thyroid receptor and PPAR for their common heterodimerization partner retinoid $\mathrm{X}$ receptor (Miyamoto et al. 1997; see Fig. 1).

Rosiglitazone occupies a small proportion of the available LBD space in PPAR $\alpha$, and less than that in PPAR $\gamma$, particularly the rosiglitazone thiazolidinedione head group, and thus comparatively reduced selectivity is observed. This characteristic has been observed for different ligands in the PPAR family, and is a clear descriptor for PPAR selectivity (Jacobs \& Lewis, 2000; MN Jacobs and DFV Lewis, unpublished results).

\section{Co-modulators that enhance or suppress transcriptional activity}

SHR interact with a group of novel nuclear proteins, including SHR coactivator-1, steroidogenic factor 1 and receptor interacting protein 140 (Luo et al. 1999). Receptor interacting protein 140 has been shown to interact with the LBD of ER in the presence of oestrogen-amplifying and -potentiating ER-dependent transcriptional activity (Sheeler et al. 2000). Steroidogenic factor 1 is a key regulator of the tissue-specific expression of the CYP steroid hydroxylases, and is essential for the embryonic survival of the primary steroidogenic organs, and the regulation of reproductive function at all three levels of the hypothalamic-pituitarygonadal axis from the earliest stages of gonadogenesis (Luo et al. 1999). In vitro studies suggest that exposure to $o, p^{\prime}$-DDT (and other oestrogenic compounds) at sufficient concentrations, or in the presence of an ER coactivator, could have a deleterious effect on normal cell function due to the untimely activation of oestrogen-regulated genes (Sheeler et al. 2000). Similarly, in a yeast two hybrid protein interaction assay, PXR has been observed to interact with SHR coactivator-1 and receptor interacting protein 140 (Masuyama et al. 2000). It has been suggested that the differences in potency of phyto-oestrogen ligands in binding studies for ER (especially ER $\beta$ ) compared with the lower potency detected in whole-cell assays, may be a consequence of interactions with binding proteins.

\section{Cytochrome P450 enzymes: 17A1/19A1 (aromatase)}

Aromatase is a key CYP in the production of oestrogen, catalysing the conversion of androgens, androstenedione and testosterone via three hydroxylation steps to oestrone and oestradiol (Martucci \& Fishman, 1993; Brodie et al. 1999). Aromatase is expressed in many tissues, including the ovaries, testis, placenta, brain, adipose tissue of the breasts, abdomen, thighs and buttocks, and bone osteoblasts. Phyto-oestrogens are potent inhibitors of aromatase (for review, see Whitten \& Patisaul, 2001).

\section{Aromatase, breast cancer and hormonal disruption in women}

Adipose tissue is the major site of oestrogen biosynthesis in post-menopausal women, with the local production of oestrogen in breast adipose tissue implicated in the development of breast cancer. Inhibition of this pathway is one method that is exploited pharmacologically in ER-positive breast cancer treatments to inhibit oestrogen production. Another approach is to inhibit oestrogen action by antioestrogens, which interact with the ER in the tumours. Recently, rosiglitazone and troglitazone, compounds known to activate another receptor, PPAR $\gamma$ (a key factor in adipocyte differentiation), and used in the control of insulin- 
resistant diabetes, have also been found to inhibit aromatase expression in human breast adipose stromal cells (Rubin et al. 2000; Simpson et al. 2000). They have also been observed to stimulate breast cancer cell lines (Mueller et al. 1998). Developmental inhibition of the aromatase pathway can give rise to polycystic ovarian syndromes (Franks et al. 1999). EDC that may affect this pathway include those that have been observed to bind with ER. Fig. 6 indicates current knowledge of the gender differences in the distribution of SHR. It is likely that there are also polymorphisms to consider, as inter-individual variations in gene sequences (Masahiko \& Honkakoski, 2000) suggest that individuals may vary in terms of amount and function of all the receptors discussed herein. The hierarchy of ligand activation differs between the receptors, as well as for receptors isolated from different species, and in many instances molecules that were previously regarded as metabolic intermediates are in fact 'intracrine' signalling molecules within tightly-coupled metabolic pathways for altering gene expression.

\section{Molecular modelling}

Using computer-generated molecular models of the ligandreceptor interaction, one can examine the mechanisms of action of SHR. By modelling such interactions and evaluating the activity of potentially hormone-mimicking materials by way of quantitative structure-activity relationships, it is possible to examine and estimate the potency differences within these compounds in human hormone receptor-ligand interactions. We are currently developing this area of study, examining the differences in affinity of SHR for a given ligand. In relation to experimental and observed data, it can provide a useful tool in a complex situation of considerable public concern. Whilst used extensively by the pharmaceutical industry, quantitative structure-activity relationships are under-utilised by nutritionists and food scientists. By using crystal structure coordinates it is possible to examine the mode of binding of selected chemicals and calculate the values for the ligandbinding affinity, when compared with in vitro data. Thus, a measure can be derived of the potency and action of a chemical with a given receptor compared with another chemical at the molecular level. This information can be related to physiological and epidemiological health effects observed, providing an essential part of the whole picture of endocrine function and dysfunction.

Data from animal and in vitro studies provide convincing evidence for the potential of phyto-oestrogens in influencing hormone-dependent states, although many in vivo studies can be confounded by the oestrogenic activity of components of the rodent diets (Boettger-Tong et al. 1998; Ashby, 2001), housing and species (Anonymous, 1999). While the clinical application of high-phyto-oestrogen human diets is in its infancy, data from preliminary studies suggest beneficial effects of importance to women's and men's health, unlike the disruptive effects observed in synthetic-EDC research.

We have generated homology three-dimensional structures of the LBD of several interrelated human SHR. These are human ER $\beta$, PXR (Fig. 7), AhR and CAR. They were produced by homology modelling from the human ER $\alpha$ crystallographic coordinates (Figs. 3 and 5; Brzozowski et al. 1997) as a template, together with the amino acid sequences for human ER $\beta$ (Mosselman et al. 1996), PXR (Lehmann et al. 1998), AhR (Burbach et al. 1992) and CAR (Forman et al. 1998) respectively. The selective endogenous ligand was docked interactively within the putative ligand binding site using the position of oestradiol in human ER $\alpha$ as a guide, and the total energy was calculated. In each receptor model a number of different ligands known to fit closely within the ligand binding site were interactively docked and binding interactions noted. Specific binding interactions included combinations of hydrogen bonding and hydrophobic contacts with key amino acid side chains, which varied depending on the nature of the ligand and receptor concerned. With $\mathrm{AhR}$ an important facet of the ligand-binding process involves a $\pi-\pi$ stacking interaction between benzene rings on selected PCB molecule and aromatic amino acid residues in the AhR ligand binding site. Differences in the binding affinities for the same ligands for ER $\alpha$ compared with ER $\beta$ are under investigation $(\mathrm{MN}$ Jacobs and DFV Lewis, unpublished results).

We also produced PPAR $\alpha$ by homology modelling using the human PPAR $\gamma$ LBD crystallographic coordinates summarised in Nolte et al. (1998) as a template, together with the amino acid sequence for human PPAR $\alpha$ (Sher et al. 1993; Lewis \& Lake, 1998). Models of selected ligands were docked interactively within the putative ligand binding site using the position of rosiglitazone as a guide, and the total energy was calculated (Jacobs \& Lewis, 2000).

The models will provide a useful tool in unravelling the complexity in the physiological response to xenobiotics, by examining the ligand-binding interactions, differences and cross-talk between the SHR and activation or inactivation by their ligands. Nuclear receptors are important drug targets for intervention in disease processes. Exogenous compounds that target these receptors can therefore disrupt both normal and abnormal functioning of these key metabolic pathways. While environmental hormone mimics contribute to detrimental health effects by activating certain receptors and disturbing normal function, there are therapeutic uses from both dietary and pharmacological treatment for abnormal functioning of the hormone pathways and hormone-dependent diseases.

The promiscuous ability of many cellular receptors to bind to ligands of different chemical structures is a major mechanism by which dietary ligands, including environmental chemicals, can enhance or inhibit receptor activation, as well as being the basis for the pharmaceutical development of receptor-regulating drugs. However, endocrine effects are mediated through multiple sites of action, and EDC are able to alter endogenous hormone pathways, as well as acting directly on receptors. Fetal exposure to EDC at critical time points will have harmful health effects that do not become evident until puberty and adulthood, and again there will be gender differences and not just agerelated susceptibilities. Vulnerability to the adverse effects of EDC exposure and protective effects from phytoprotectants such as phyto-oestrogens escalates during dynamic periods of growth and development. Children may metabolize compounds faster, but they detoxify more slowly 
and have greater body burdens, due to higher dietary intakes in relation to body size compared with adults.

The effect of ligand binding to a SHR needs to be considered as a synthesis of the entire endocrine system, over time, according to gender and reproductive status and with due consideration for environmental factors.

\section{Conclusion}

The nuclear receptors modelled display a spectrum of ligand specificities, ranging from the highly specific, as seen in CAR (which binds $5 \alpha$-androstan-3 $\alpha$-ol (androstanol), but not $5 \alpha$-androstan-3 $\beta$-o1) and in PPAR selectivity, to the highly non-specific, such as human PXR which is very flexible, and can bind with a large number of wide-ranging molecules from rifampicin to steroidal structures. They also display a spectrum of binding modes within the LBD, from hydrogen bonding with variable key amino acids (as observed in all the receptors) to $\pi-\pi$ stacking, as seen in the AhR, and also binding outside the LBD, as seen with antagonists such as tamoxifen in ERo.

The identification and in silico (a test done via computer) assessment of the different ligands both in isolation and within the receptor models will add to a better knowledge of their specificity. Furthermore, it may help to explain the selective action of oestrogens, phyto-oestrogens and EDC in different tissues, and to expand knowledge on the role of nutrition and pharmacology for therapeutic intervention in various endocrine, developmental and energy homeostasis functions that involve the ER, AhR, CAR, PXR and the PPAR. Pervasive EDC that target these receptors, disrupting normal functioning of key metabolic pathways, contribute to detrimental side effects in just the same way as can be observed pharmacologically, with the inadvertent activation of orphan receptors by certain drugs. Without considering the whole SHR superfamily, current EDC research can only be considered piecemeal, insufficient and ineffective for risk assessment, and not representative of the hormonal effects of EDC. The full range of effects of EDC (whether of synthetic or plant origin), from exposure routes to health outcomes, on women, men and subsequent generations can only be unravelled with an integrated multidisciplinary approach. Since this review paper was written the crystal structures of PXR (Watkins et al. 2001) and PPAR alpha (Xu et al. 2001) have been published. The models reported here compare favourably with the crystal structures.

\section{Acknowledgements}

M.J. is supported by a BBSRC and GlaxoWellcome CASE studentship.

\section{References}

Abbott BD, Schmid JE, Pitt JA, Buckalew AR, Wood CR, Held GA \& Diliberto JJ (1999) Adverse reproductive outcomes in the transgenic Ah receptor-deficient mouse. Toxicology and Applied Pharmacology 155, 62-70.

Adami H-O, Bergström R, Möhner M, Zatonski W, Storm H, Ekbom A, Tretli S, Teppo L, Zeigler H, Rahu M, Gurevicius R
\& Stengrevics A (1994) Testicular cancer in nine northern European countries. International Journal of Cancer 59, 33-38.

Adlercrutz H (1998) Evolution, nutrition, intestinal microflora and prevention of cancer: A hypothesis. Proceedings of the Society of Experimental Biology and Medicine 217, 241-246.

Ahlborg UG, Lipworth L, Titus-Ernstoff L, Hsieh C-C, Hanberg A, Baron J, Trichopolous DM \& Adami H-O (1995) Organochlorine compounds in relation to breast cancer, endometrial cancer, and endometriosis: An assessment of the biological and epidemiological evidence. Critical Reviews in Toxicology 25, 463-531.

Alberts B, Bray D, Johnson A, Lewis J, Raff M, Roberts K \& Walter P (1997) Essential Cell Biology. New York and London: Garland Publishing.

Andersson A-M \& Skakkebæk NE (1999) Exposure to exogenous estrogens in food: possible impact on human development and health. European Journal of Endocrinology 140, 477-485.

Anonymous (1999) Hormone studies flawed, researcher warns. Chemistry and Industry 18 October issue, 784.

Arnold SF, Klotz DM, Collins BM, Vonier PM, Guillette LJ Jr \& McLachlan JA (1996) Synergistic activation of estrogen receptor with combinations of environmental chemicals. Science 272, 1489-1492.

Arnold SF, Vonier PM, Collins BM, Klotz DM, Guillette LJ Jr \& McLachlan JR (1997) In vitro synergistic interaction of alligator and human estrogen receptors with combinations of environmental chemicals. Environmental Health Perspectives 105, 615-632.

Ashby J (2001) Testing for endocrine disruption post EDSTAC: extrapolation from low dose rodent effects to humans. Toxicology Letters 120, 233-242.

Ashby J, Tinwell H, Soames A \& Foster J (1999) Induction of hyperplasia and increased DNA content in the uterus of immature rats exposed to coumestrol, Environmental Health Perspectives 107, 819-822.

Auger J, Kunstmann JM, Czyglik F \& Jouannet P (1995) Decline in semen quality among fertile men in Paris during the past 20 years. New England Journal of Medicine 332, 281-285.

Baes M, Gulick T, Choi H-S, Martinoli MG, Simha D \& Moore DD (1994) A new orphan member of the nuclear hormone receptor superfamily that interacts with a subset of retinoic acid response elements. Molecular and Cellular Biology 14, 1544-1552.

Barkhem T, Carlsson B, Nilsson Y, Enmark E, Gustafsson J-Å \& Nilsson S (1998) Differential response of estrogen receptor $\alpha$ and estrogen receptor $\beta$ to partial estrogen agonists/antagonists. Molecular Pharmacology 54, 105-112.

Bar-Tana J (2001) Peroxisome proliferator-activated receptor gamma (PPAR $\gamma$ ) activation and its consequences in humans. Toxicology Letters 120, 9-19.

Bernstein L \& Press MF (1998) Does estrogen receptor expression in normal breast tissue predict breast cancer risk? Journal of the National Cancer Institute 90, 5-7.

Bingham SA, Atkinson C, Liggins J, Bluck L \& Coward A (1998) Phyto-oestrogens: where are we now? British Journal of Nutrition 79, 393-406.

Birnbaum LS (2000) Health effects of dioxins: people are animals and vice versa! Organohalogen Compounds 49, 101-103.

Blumberg B \& Evans RM (1998) Orphan nuclear receptors - new ligands and new possibilities. Genes and Development 12, 3149-3155.

Blumberg B, Sabbagh W, Juguilon H, Bolado J, van Meter CM, Ong ES \& Evans RM (1998) SXR, a novel steroid and xenobiotic sensing nuclear receptor. Genes and Development 12, 3195-3205.

Boettger-Tong H, Murthy L, Chiappetta C, Kirkland JL, Goodwin B, Adlercreutz H, Stancel GM \& Makela S (1998) A case of a 
laboratory animal feed with high estrogenic activity and its impact on in vivo responses to exogenously administered estrogens. Environmental Health Perspectives 106, 369-373.

Bradbury RB \& White DE (1954) Estrogens and related substances in plants. Vitamins and Hormones 12, 207-233.

Bradlow HL, Davis DL, Lin G, Sepovic D \& Tiwari R (1995) Effects of pesticides on the ratio of 16 alphahydroxyestrone/ 2hydroxyestrone: a biologic marker of breast cancer risk. Environmental Health Perspectives 103, 147-150.

Bradlow HL, Davis D, Sepkovic DW, Tiwari R \& Osbourne MP (1997) Role of the estrogen receptor in the action of organochlorine pesticides on estrogen metabolism in human breast cancer cell lines. Science of the Total Environment 208, 9-14.

Brodie A, Lu Q \& Long B (1999) Aromatase and its inhibitors. Journal of Steroid Biochemistry and Molecular Biology 69, 205-210.

Brzozowski AM, Pike AC, Dauter Z, Hubbard RE, Bonn T, Engstrom O, Ohman L, Greene GL, Gustafsson J-Å \& Carlquist M (1997) Molecular basis of agonism and antagonism in the oestrogen receptor. Nature 389, 753-758.

Burbach KM, Poland A \& Bradfield CA (1992) Cloning of the Ah-receptor cDNA reveals a distinctive ligand-activated transcription factor. Proceedings of the National Academy of Sciences USA 89, 815-819.

Burow ME, Tang Y, Collins-Burow BM, Krajewski S, Reed JC, McLachlan JA \& Beckman BS (1999) Effects of environmental estrogens on tumor necrosis factor $\alpha$-mediated apoptosis in MCF-7 cells. Carcinogenesis 20, 2057-2061.

Cassidy A (1996) Physiological effects of phyto-oestrogens in relation to cancer and other human health risks. Proceedings of the Nutrition Society 55, 399-417.

Cassidy A \& Faughnan M (2000) Phyto-oestrogens through the life cycle. Proceedings of the Nutrition Society 59, 489-496.

Cassidy A \& Milligan S (1998) How significant are environmental oestrogens to women? Climeractic 1, 229-242.

Choi H-S, Chung M, Tzameli I, Simha D, Lee Y-K, Seol W \& Moore DD (1997) Differential transactivation by two isoforms of the orphan nuclear hormone receptor CAR. Journal of Biological Chemistry 272, 23565-23571.

Colburn T, Dumanoski D \& Myers JP (1999) Our Stolen Future: Are We Threatening Our Fertility, Intelligence, and Survival? A Scientific Detective Story. New York: Dutton.

Colburn T, Vom Saal FS \& Soto AM (1993) Developmental effects of endocrine disrupting chemicals in wildlife and humans. Environmental Health Perspectives 101, 378-384.

Collett GP, Betts AM, Johnson MI, Pulimood AB, Cook S, Neal DE \& Robson CN (2000) Peroxisome proliferator-activated receptor $\alpha$ is an androgen responsive gene in human prostate and is highly expressed in prostatic adenocarcinoma. Clinical Cancer Research 6, 3241-3248.

Crain DA, Rooney AA, Orlando EF \& Guillette LJ Jr (2000) Endocrine disrupting contaminants and hormone dynamics: Lessons from wildlife. In Environmental Endocrine Disruptors, an Evolutionary Perspective, pp. 1-21 [L Guillette Jr and DA Crain, editors]. New York: Taylor \& Francis.

Davidson NE \& Yager JD (1997) Pesticides and breast cancer: Fact or fad? Journal of the National Cancer Institute 89, 1743-1744.

Davis DL, Bradlow HL, Wolff M, Woodruff T, Hoel DG \& AntonCulver H (1993) Medical hypothesis: Xenoestrogens as preventable causes of breast cancer. Environmental Health Perspectives 101, 372-377.

Davis DL, Telang NT, Osborne MP \& Bradlow HL (1997) Medical hypothesis: bifunctional genetic-hormonal pathways to breast cancer. Environmental Health Perspectives 105, 571-576.

Diliberto JJ, Abbot BD \& Birnbaum LS (2000) Use of AhR knockout (AhR-/-) mice to investigate the role of the Ah receptor on the disposition of TCDD. Organohalogen Compounds 49 , 121-123.

Dotzlaw H, Leygue E, Watson P \& Murphy LC (1999) The human orphan receptor PXR messenger RNA is expressed in both normal and neoplastic breast tissue. Clinical Cancer Research $\mathbf{8}$, 2103-2107.

Ebling FJP, Brooks AN, Cronin AS, Ford H \& Kerr JB (2000) Estrogenic induction of spermatogenesis in the hypogonadal mouse. Endocrinology 141, 2861-2869.

Falck F Jr, Ricci A Jr, Wolff MS, Godbold J \& Deckers P (1992) Pesticides and polychlorinated biphenyl residues in human breast lipids and their relation to breast cancer. Archives of Environmental Health 47, 143-146.

Food and Agriculture Organization/World Health Organization (1998a) Residues of Some Veterinary Drugs in Animals and Foods. FAO Food and Nutrition Paper no. 41. Rome: FAO.

Food and Agriculture Organization/World Health Organization (1988b) Evaluation of Certain Veterinary Drugs Residues in Food. WHO Technical Report Series no. 763. Geneva: WHO.

Forman BM, Tzameli I, Choi H-S, Chen J, Simha D, Seol W, Evans RM \& Moore DD (1998) Androstane metabolites bind to and deactivate the nuclear receptor CAR- $\beta$. Nature 395, 612-615.

Franks S, Gharani N \& Gilling-Smith C (1999) Polycystic ovary syndrome: evidence for a primary disorder of ovarian steroidogenesis. Journal of Steroid Biochemistry and Molecular Biology 69, 269-272.

Fujimoto J, Hirose R, Sakaguchi H \& Tamaya T (2000) Clinical significance of expression of estrogen receptor alpha and beta mRNA in ovarian cancers. Oncology 58, 334-341.

Fuqua SAW, Wiltschke C, Zhang QX, Borg $\AA$, Castles CG, Friedrichs WE, Hopp T, Hilsenbeck S, Mohsin S, O'Connell P \& Allred DC (2000) A hypersensitive estrogen receptor alpha mutation in premalignant breast lesions. Cancer Research 60 , 4026-4029.

Gaido KW, Leonard LS, Maness SC, Hall JM, McDonnell DP, Saville B \& Safe S (1999) Differential interaction of the methoxychlor metabolite 2,2-bis-( $p$-hydroxyphenyl)-1,1,1tricloroethane with estrogen receptors $\alpha$ and $\beta$. Endocrinology 140, 5746-5753.

Gillner M, Bergman J, Ambilleau C, Feruström B \& Gustafsson J-Å (1993) Interactions of indolo [3-2-6] carbazoles and related polycyclic aroma hydrocarbons with specific binding sites for $2,3,7,8$-tetrachlorodobenzo- $p$-dioxin in rat liver. Molecular Pharmacology 28, 336-345.

Giwercman A, Carlsen E, Keiding N \& Skakkebaek NE (1993) Evidence for the increasing incidence of abnormalities of the human testis: A review. Environmental Health Perspectives 102, Suppl., 65-71.

Gray EL, Kelce WR, Wiese T, Tyl R, Gaido K \& Cook J (1997) Endocrine screening methods workshop report: detection of estrogenic and androgenic hormonal and antihormonal activity for chemicals that act via receptor or steroidogenic enzyme mechanisms. Reproductive Toxicology 11, 719-750.

Guillette LJ \& McLachlan JA (1996) Ecosystems and embryos - is there a scientific basis for concern? Animal Reproduction Science 42, 13-24.

Gustafsson J-Å (1999) Estrogen receptor $\beta$ - a new dimension in estrogen mechanism of action. Journal of Endocrinology 163, 379-383.

Gustaffson J- $\AA$ (2000) The role of the ER $\beta$ in oestrogen mediated carcinogenesis. Toxicology Letters 116, 1.

Hahn ME (1998) The aryl hydrocarbon receptor: a comparative perspective. Comparative Biochemistry and Physiology 121C, 23-53.

Hall JM \& McDonnell DP (1999) The estrogen receptor $\beta$-isoform (ER $\beta)$ of the human estrogen receptor modulates ER $\alpha$ transcriptional activity and is a key regulator of the cellular 
response to estrogens and antiestrogens. Endocrinology 140, 5566-5578.

Heath-Pagliuso S, Rogers WJ, Tullis K, Seidel SD, Cenijin PH, Brouwer A \& Denison MS (1998) Activation of the Ah receptor by tryptophan and tryptophan metabolites. Biochemistry 37, $11508-11515$.

Hess RA, Bunick D, Lee K-H, Bahr J, Taylor JA, Korach KS \& Lubahn DB (1997) A role for oestrogens in the male reproductive system. Nature 390, 509-512.

Hillman GG, Forman JD, Kucuk O, Yudelev M, Maughan RL, Rubio J, Layer A, Tekyi-Mensah S, Abrams J \& Sarkar FH (2001) Genistein potentiates the radiation effect on prostrate carcinoma cells. Clinical Cancer Research 7, 382-390.

Honkakoski P, Zelko I, Sueyoshi T \& Negishi M (1998) The nuclear orphan receptor CAR-retinoid $\mathrm{X}$ receptor heterodimer activates the phenobarbital-responsive enhancer nodule of the CYP2B gene. Molecular and Cellular Biology 18, 5652-5658.

Howdeshell KL, Hotchkiss AK, Thayer KA, Vandenbergh JG \& vom Saal FS (1999) Exposure to bisphenol $\alpha$ advances puberty. Nature 401, 763-765.

Hunter DJ, Hankinson SE, Laden F, Colditz GA, Manson JE, Willet WC, Speizer FE \& Wolff MS (1997) Plasma organochlorine levels and the risk of breast cancer. New England Journal of Medicine 337, 1253-1258.

Hunter DJ \& Kelsey KT (1993) Pesticide residues and breast cancer. The harvest of a silent spring. Journal of the National Cancer Institute 85, 598-599.

Jacobs MN (1998) Molecular modelling of oestrogenic compounds in the human oestrogen receptor and investigation of the activity of oestrogenic compounds in breast cancer cell lines. MSc Thesis, University of Surrey.

Jacobs MN, Covaci A \& Schepens P (2001a) Investigation of polybrominated diphenyl ether in Scottish and European farmed atlantic salmon (Salmo salar), salmon aquaculture feed and fish oils. Organohalogen Compounds 51, 239-242.

Jacobs MN, Covaci A, Schepens P \& Millstone E (2001b) Investigation of selected PCBs and organochlorine pesticides in farmed atlantic salmon (Salmo salar), salmon aquaculture feed and fish oil components of the feed. Organohalogen Compounds 51, 314-318.

Jacobs MN, Ferrario J \& Byrne C (2000) Investigation of PCDDs, PCDFs and selected coplanar PCBs in Scottish farmed Atlantic salmon. Organohalogen Compounds 47, 338-341.

Jacobs MN \& Lewis DFV (1999) A QSAR study of organochlorine and isoflavonoid compounds ligand binding affinity to the human oestrogen receptor $\alpha$. Organohalogen Compounds 41, 517-520.

Jacobs MN \& Lewis DFV (2000) Homology modelling of the human peroxisome proliferator activated receptor $\alpha$ (PPAR $\alpha$ ) ligand binding domain from the human PPAR $\gamma$ crystal structure. Toxicology Letters 116, Suppl. 1, 59.

Jacobs MN, Starkey S \& Hoffman R (1999) Combination effects of different ratios of PCB 153 and the phytoestrogen genistein upon DNA synthesis in an MCF-7 breast cancer cell line. Organohalogen Compounds 42, 73-77.

Johnson TE, Holloway MK, Vogel R, Rutledge SJ, Perkins JJ, Rodan GA \& Scmidt A (1997) Structural requirements and cell type specifity for ligand activation of peroxisome proliferator activated receptors. Journal of Steroid Biochemistry and Molecular Biology 63, 1-8.

Jones SA, Moore LB, Shenk JL, Wisley GB, Hamilton GA, McKee DD, Tomkinson NCO, LeCluyse EL, Lambert MH, Willson TM, Kliewer SA \& Moore JT (2000) The pregnane X receptor: A promiscuous xenobiotic receptor that has diverged during evolution. Molecular Endocrinology 14, 27-39.

Kelce RW, Stone RC, Laws CS, Gray EL, Kemppainen AJ \& Wilson ME (1995) Persistent DDT metabolite $p, p^{\prime}$-DDE is a potent androgen receptor antagonist. Nature 373, 581-585.
Kelley ST \& Thackray VG (1999) Phylogenetic analyses reveal ancient duplication of estrogen receptor isoforms. Journal of Molecular Evolution 49, 609-614.

Klein KO, Baron J, Colli MJ, McDonnell DP \& Cutler GB Jr (1994) Estrogen levels in childhood determined by ultrasensitive recombinant cell bioassay. Journal of Clinical Investigation 94, 2475-2480.

Kliewer SA, Lehmann JM \& Willson TM (1999) Orphan nuclear receptors: Shifting endocrinology into reverse. Science 284, 757-760.

Kliewer SA, Moore JT, Wade L, Staudinger JL, Watson MA, Jones SA, McKee DD, Oliver BB, Willson TM, Zetterström RH, Perlmann T \& Lehmann JM (1998) An orphan nuclear receptor activated by pregnanes defines a novel steroid signaling pathway. Cell 92, 73-82.

Kreiger N, Wolff MS, Hiatt RA, Rivera M, Vogelman J \& Orentreich N (1994) Breast cancer and serum organochlorines: a prospective study among white, black and Asian women. Journal of the National Cancer Institute 86, 589-599.

Krstevska-Konstantinova M, Charlier C, Craen M, Du Caju M, Heinrichs C, de Beaufort C, Plomteux G \& Bourguignon JP (2001) Sexual precocity after immigration from developing countries to Belgium: evidence of previous exposure to organochlorine pesticides. Human Reproduction 16, 1020-1020.

Kuiper GCJM, Carlsson B, Grandien K, Enmark E, Haggblad J, Nilsson S \& Gustafsson J-A (1997) Comparison of the ligand binding specificity and transcript tissue distribution of estrogen receptors alpha and beta. Endocrinology 138, 863-870.

Kuiper GCJM, Lemmen JG, Carlsson B, Corton JC, Safe SH, van der Saag PT, van der Burg B \& Gustafsson J-Å (1998) Interaction of estrogenic chemicals and phytoestrogens with estrogen receptor ß. Endocrinology 139, 4252-4263.

Lamartinière CA, Moore J, Holland MB \& Barnes S (1995) Neonatal genistein chemoprevents mammary carcinogenesis. Proceedings of the Society of Experimental Biology and Medicine 208, 120-123.

Lau K-M, LaSpina M, Long J \& Ho S-M (2000) Expression of estrogen receptor (ER) ER- $\beta$ in normal and malignant prostatic epithelial cells: regulation by methylation and involvement of growth regulation. Cancer Research 60, 3175-3182.

Lau K-M, Mok SC \& Ho S-M (1999) Expression of human estrogen receptor $\alpha$ and $\beta$, progesterone receptor and androgen receptor mRNA in normal and malignant ovarian epithelial cells. Proceedings of the National Academy of Sciences USA 96, 5722-5727.

Lehmann JM, McKee DD, Watson MA, Willson TM, Moore JT \& Kliewer SA (1998) The human orphan nuclear receptor PXR is activated by compounds that regulate CYP3A4 gene expression and cause drug interactions. Journal of Clinical Investigation 102, 1016-1023.

Lewis DFV \& Jacobs MN (1999) A QSAR study of some PCBs ligand-binding affinity to the cytosolic Ah receptor. Organohalogen Compounds 41, 537-540.

Lewis DFV \& Lake B (1998) Molecular modelling of the rat peroxisome proliferator-activated receptor $\alpha(\mathrm{rPPAR} \alpha)$ by homology with the human retinoic acid X receptor $\alpha$ (hRAR $\alpha)$ and investigation of peroxisome proliferator binding interactions: QSARs. Toxicology In Vitro 12, 619-632.

Liem AKD, Fürst P \& Rappe C (2000) Exposure of populations to dioxins and related compounds. Food Additives and Contaminants 17, 241-259.

Luo X, Ikeda Y, Lala D, Rice D, Wong M \& Parker KL (1999) Steroidogenic factor-1 (SF-1) is essential for endocrine development and function. Journal of Steroid Biochemistry and Molecular Biology 69, 13-18.

McLachlan JA (1997) Synergistic effect of environmental oestrogens: report withdrawn. Science 277, 463-464. 
McLachlan JA Burow M, Chiang T-C \& Fang Li S (2001) Gene imprinting in developmental toxicology: a possible interface between physiology and pathology. Toxicology Letters 120, 161-164.

Martucci CP \& Fishman J (1993) P450 enzymes of estrogen metabolism. Pharmacology Therapy 57, 237-257.

Masahiko N \& Honkakoski P (2000) Induction of drug metabolism by nuclear receptor CAR: molecular mechanisms and implications for drug research. European Journal of Pharmacological Sciences 11, 259-264.

Masuyama H, Hiramatsu Y, Kunitomi M, Kudo T \& MacDonald PN (2000) Endocrine disrupting chemicals, phthalic acid and nonylphenol, activate pregnane $\mathrm{X}$ receptor-mediated transcription. Molecular Endocrinology 14, 421-428.

Matthews JB, Twomey K \& Zacharewski TR (2001) In vitro and in vivo interactions of bisphenol $\mathrm{A}$ and its metabolite, bisphenol $\mathrm{A}$ glucuronide, with estrogen receptors $\alpha$ and $\beta$. Chemical Research in Toxicology 14, 149-157.

Maurel P (1996) The CYP3A family. In Cytochromes P450: Metabolic and Toxicological Aspects, pp. 241-270 [C Ionnides, editor]. Boca Raton, FL: CRC Press Inc.

Meerts IATM, Letcher RJ, Hoving S, Marsh G, Bergman A, Lemmen JG, van der Berg B \& Brouwer A (2001) In vitro estrogenicity of polybrominated diphenyl ethers, hydroxylated PBDEs and polybrominated bisphenol A compounds. Environmental Health Perspectives 109, 399-407.

Memon RA, Tecott LH, Nonogaki K, Beigneux A, Moser AH, Grunfeld C \& Feingold KR (2000) Up-regulation of peroxisome proliferator-activated receptor $\alpha(\operatorname{PPAR} \alpha)$ and PPAR $\gamma$ messenger ribonucleic acid expression in the liver in murine obesity: Troglitazone induces expression of PPAR $\gamma$ responsive adipose tissue-specific genes in the liver of obese diabetic mice. Endocrinology 141, 4021-4031.

Milligan SR, Balasubramanian AV \& Kalita JC (1998) Relative potency of xenobiotic estrogens in an acute in vivo mammalian assay. Environmental Health Perspectives 106, 23-26.

Milligan SR, Kalita JS, Heyerick A, Rong H, De Coomsan L \& De Keukeleire D (1999) Identification of a potent phytoestrogen in hops (Humulus lupulus L.) and beer. Journal of Clinical Endocrinology and Metabolism 84, 2249-2252.

Miyamoto T, Keneko A, Kakizawa T, Yajima H, Kamijo K, Sekine R, Hiramatsu K, Nishii Y, Hashimoto T \& Hashizume K (1997) Inhibition of peroxisome proliferator signaling pathways by thyroid hormone recepter - competitive binding to the response element. Journal of Biological Chemistry 272, $7752-7758$.

Moore LB, Goodwin B, Jones SA, Wisely GB, Willson TM, Collins JL \& Kliewer SA (2000) St. John's Wort induces hepatic drug metabolism through activation of the pregnane $\mathrm{X}$ receptor. Proceedings of the National Academy of Sciences USA 97, 7500-7502.

Mosselman S, Polman J \& Dijkema R (1996) ER beta: Identification and characterization of a novel human estrogen receptor. FEBS Letters 392, 49-53.

Mueller E, Sarraf P, Tontonoz P, Evans RM, Martin KJ, Zhang M, Fletcher C, Singer S \& Spiegelman BM (1998) Terminal differentiation of human breast cancer through PPAR gamma. Molecular Cell 1, 465-470.

National Institute of Environmental Health Sciences, National Institutes of Health (2001) National Toxicology Program's Report of the endocrine disruptors low-dose peer review. http://ntpserver.niehs.nih.gov/htdocs/liason/LowDosePeerFinalRpt.pdf.

Nelson KG, Sakai Y, Eitzman B, Steed T \& McLachlan JA (1994) Exposure to diethylstilbestrol during a critical developmental period of the mouse reproductive tract leads to persistent induction of two estrogen regulated genes. Cell Growth and Differentiation 5, 595-606.
Nelson KG, Takahashi T, Bossert NL, Walmer DK \& McLachlan JA (1991) Epidermal growth factor replaces estrogen in the stimulation of female genital tract growth and differentiation. Proceedings of the National Academy of Sciences USA 88, 21-25.

Newbold RR, Padilla Banks E, Bullock B \& Jefferson WN (2001) Uterine adenocarcinoma in mice treated neonatally with genistein. Cancer Research 61, 4325-4328.

Nguyen TA, Hoivik D, Lee J-E \& Safe S (1999) Interactions of nuclear receptor coactivator/corepressor proteins with the aryl hydrocarbon receptor complex. Archives of Biochemistry and Biophysics 367, 250-257.

Nolte RT, Wisely GB, Westin S, Cobb JE, Lambert MH, Kurokawa R, Rosenfeld MG, Willson TM, Glass CK \& Milburn MV (1998) Ligand binding and co-activator assembly of the peroxisome proliferator-activated receptor-gamma. Nature $\mathbf{3 9 5}$, 137-143.

Ogawa S, Chan J, Chester AE, Gustafsson J-A, Korach KS \& Pfaff DW (1999) Survival of reproductive behaviours in estrogen receptor beta gene-deficient ( $\beta E R K O)$ male and female mice. Proceedings of the National Academy of Science USA 96, 12887-12892.

Paech K, Webb P, Kuiper GGJM, Nilsson S, Gustafsson J-Å, Kushner PJ \& Scanlan TS (1997) Differential ligand activation of estrogen receptors ER $\alpha$ and ER $\beta$ at AP1 sites. Science 277, $1508-1510$.

Parker MG (1993) Steroid and related receptors. Current Opinion in Cell Biology 5, 499-504.

Pascussi J-M, Jounaidi Y, Drocourt L, Domergue J, Balabaud C, Maurel P \& Vilarem M-J (1999) Evidence for the presence of a functional pregnane $\mathrm{X}$ receptor response element in the CYP3A7 promoter gene. Biochemical and Biophysical Research Communications 260, 377-381.

Payne J, Scholze M \& Kortenkamp A (2001) Mixtures of four organochlorines enhance human breast cancer cell proliferation. Environmental Health Perspectives 109, 391-397.

Petersen DN, Tkalcevic GT, Koza-Taylor PH, Turi TG \& Brown TA (1998) Identification of estrogen receptor beta (2), a functional variant of estrogen receptor beta expressed in normal rat tissues. Endocrinology 139, 1082-1092.

Petreas M, She J, Winkler P, McKinney M, Reynolds P, Smith D, Gilliss D, Hurley S, Jeffrey S \& Mahoney ME (1998) Levels of PCDD/PCDFs, PCBs and OC pesticides in breast adipose tissue of women enrolled in a California breast cancer study. Organohalogen Compounds 38, 37-40.

Phelan D, Winter GM, Rogers WJ, Lam JC \& Dennison MS (1998) Activation of the Ah Receptor signal transduction pathway by bilrubin and biliverdin. Archives of Biochemistry and Biophysics 357, 155-163.

Poellinger L (2000) Mechanistic aspects - the dioxin (aryl hydrocarbon) receptor. Food Additives and Contaminants 17, 261-266.

Porta M, Malats N, Jariod M, Grimault JO, Rifà J, Carrato A, Guarner L, Salas A, Santiago-Silva M, Corominas JM, Andreu M \& Real FX (1999) Serum concentrations of organochlorine compounds and K-ras mutations in exocrine pancreatic cancer. Lancet 354, 2125-2129.

Ramamoorthy K, Wang K, Chen I-C, Safe S, Norris JD, McDonnell DP, Gaido KW, Bocchinfuso WP \& Korach KS (1997) Potency of combined estrogenic pesticides. Science 275, 405-406.

Ross JL, Cassorla FG, Skerda MC, Valk IM, Loriaux DL \& Cutler GB (1983) A preliminary study of the effect of estrogen dose on growth in Turner's syndrome. New England Journal of Medicine 309, 1104-1106.

Ross JL, Long LM, Skerda MC, Cassorla FG, Kurtz D, Loriaux DL \& Cutler GB (1986) Effects of low doses of estradiol on 6-month growth rates and predicted height in patients with Turner syndrome. Journal of Pediatrics 109, 150-953. 
Rubin GL, Zhao Y, Kalus AM \& Simpson ER (2000) Peroxisome proliferator-activated receptor $\gamma$ ligands inhibit estrogen biosynthesis in human breast tissue: possible implications for breast cancer therapy. Cancer Research 60, 1604-1608.

Safe S (1997) Xenoestrogens and breast cancer. New England Journal of Medicine 337, 1303-1304.

Safe S, Connor K, Ramamoorthy K, Gaido K \& Maness S (1997) Human exposure to endocrine-active chemicals: hazard assessment problems. Regulatory Toxicology and Pharmacology 26, 52-58.

Safe SH (1995) Environmental and dietary estrogens and human health: is there a problem? Environmental Health Perspectives 103, 346-351.

Scheutz EG, Brimer C \& Schuetz JD (1998) Environmental xenobiotics and the antihormones cyproterone acetate and spironolactone use the nuclear hormone pregnenolone $\mathrm{X}$ receptor to activate the CYP3A23 hormone response element. Molecular Pharmacology 54, 1113-1117.

Sharpe RM (1997) Do males rely on female hormones? Nature 390, 447-448.

Sharpe RM (2001) Hormones and testis development and the possible adverse effects of environmental chemicals. Toxicology Letters 120, 221-232.

Sharpe RM, Atanassova N, McKinnell C, Parte P, Turner KJ, Fisher JS, Kerr JB, Groome NP, Macpherson S, Millar MR \& Saunders PTK (1998) Abnormalities in functional development of the Sertoli cells in rats treated neonatally with diethylstilbestrol: A possible role for estrogens in Sertoli cell development. Biology of Reproduction 59, 1084-1094.

Sharpe RM \& Skakkebæk NE (1993) Are oestrogens involved in falling sperm counts and disorders of the reproductive tract? Lancet 341, 1392-1395.

Sheeler CQ, Dudley MW \& Khan SA (2000) Environmental estrogens induce transcriptionally active estrogen receptor dimers in yeast: Activity potentiated by the coactivator RIP140. Environmental Health Perspectives 108, 97-103.

Shen K \& Novak RF (1997a) Differential effects of aroclors and DDT on growth factor gene expression and receptor tyrosine kinase activity in human breast epithelial cells. Advances in Experimental Medicine and Biology 407, 295-302.

Shen K \& Novak RF (1997b) DDT stimulates c-erbB2, c-met, and STATS tyrosine phosphorylation, Grb2-sos association, MAPK phosphorylation, and proliferation of human breast epithelial cells. Biochemical and Biophysical Research Communications 231, 17-21.

Sher T, Yi H-F, McBride OW \& Gonzalez FJ (1993) cDNAcloning, chromosomal mapping, and functional characterization of the human peroxisome proliferator activated receptor. Biochemistry 32, 5598-5604.

Shughrue PJ \& Merchenthaler I (2000) Estrogen is more than just a sex hormone: Novel sites for estrogen action in the hippocampus and cerebral cortex. Frontiers in Neuroendocrinology 21, 95-101.

Simpson ER, Rubin G, Clyne C, Robertson K, O’Donnell L, Jones M \& Davis S (2000) The role of local estrogen biosynthesis in males and females. Trends in Environmental Medicine 11, 184-188.

Sinal CJ \& Bend RJ (1997) Aryl hydrocarbon receptor-dependent induction of Cyplal by bilirubin in mouse hepatatoma hepa $1 \mathrm{clc} 7$ cells. Molecular Pharmacology 52, 590-599.

Soto AM, Sonnenschein C, Chung KL, Fernandez MF, Olea N \& Serrano FO (1995) The E-SCREEN assay as a tool to identify estrogens: an update on estrogenic environmental pollutants. Environmental Health Perspectives 103, 113-122.

Stevens JT, Breckenridge CB, Wetzel LT, Gillis JH, Luempert LG \& Eldridge LC (1994) Hypothesis for mammary tumourigenesis in Sprague-Dawley rats exposed to certain triazine herbicides. Journal of Toxicology and Environmental Health 43, 139-153.

Tetsuka M, Anderson RA \& Hillier SG (1997) Distribution of messenger RNA's encoding oestrogen receptor isoforms in female reproductive tissues. Journal of Endocrinology 152, OC20.

Tielemans E, van Kooij R, Te Velde ER, Burdoff A \& Heederik D (1999) Pesticide exposure and decreased fertilisation rates in vitro. Lancet 354, 484-485.

Uauy R, Mena P \& Rojas C (2000) Essential fatty acids in early life: structural and functional role. Proceedings of the Nutrition Society 59, 3-15.

United Nations Environment Programme (2001) The Stockholm Convention on Persistent Organic Pollutants. http://www.chem. unep.ch/pops/

US Environmental Protection Agency (2001) Endocrine disrupter screening program. http://www.epa.gov/scipoly/oscpendo/ index.htm

US Food and Drug Administration (1999) Guideline 3, part 2: Guideline for toxicological testing. http://www.fda.gov/dms/ pestpts.html

Warner M, Nilsson S \& Gustafsson J-Å (1999) The estrogen receptor family. Current Opinion in Obstetrics and Gynecology 11, 249-254.

Watkins RE, Wisely GB, Moore LB, Collins JL, Lambert MH, Williams SP, Willson TM, Kliewer SA \& Redinbo MR (2001) The human nuclear xenobiotic receptor PXR structural determinants of directed promiscuity. Science 292, 2329-2333.

Waxman DJ (1999) P450 gene induction by structurally diverse xenochemicals: central role of nuclear receptors CAR, PXR, and PPAR. Archives of Biochemistry and Biophysics 369, 11-23.

Weigel N (1996) Steroid hormone receptors and their regulation by phosphorylation. Biochemical Journal 319, 657-667.

Whitten PL \& Patisaul HB (2001) Cross species and interassay comparisons of phytoestrogen action. Environmental Health Perspectives 109, 5-17.

Willson TM, Brown PJ, Sternbach DD \& Henke BR (2000) The PPARs: from orphan receptors to drug discovery. Journal of Medicinal Chemistry 43, 527-550.

Wise PM, Dubal DB, Wilson ME, Rau SW \& Böttner M (2001) Minireview: Neuroprotective effects of oestrogen - New insights into mechanisms of action. Endocrinology 142, 969-973.

Wolff MS \& Toniolo PG (1995) Environmental organochlorine exposure and potential etiologic factor in breast cancer. Environmental Health Perspectives 103, 141-145.

Wolff MS, Toniolo PG, Lee EW, Rivera M \& Dubin N (1993) Blood levels of organochlorine residues and risk of breast cancer. Journal of the National Cancer Institute 85, 648-652.

Xie W, Barwick JL, Simon CM, Pierce AM, Safe S, Blumberg B, Guzelian PS \& Evans RE (2000) Reciprocal activation of xenobiotic response genes by nuclear receptors SXR/PXR and CAR. Genes and Development 14, 3014-3023.

$\mathrm{Xu}$ HE, Lambert MH, Montana VG, Plunket KD, Moore LB, Collins JL, Oplinger JA, Kliewer SA, Gampe Jr RT, McKee DD, Moore JT \& Willson TM (2001) Structural determinants of ligand binding selectivity between the peroxisome proliferatoractivated receptors. Procedings of the National Academy of Sciences USA 98, 13919-13924.

Zhou J-R \& Lee AS (1998) Mechanism for the suppression of the mammalian stress response by genistein, an anticancer phytoestrogen from soy. Journal of the National Cancer Institute 90, 381-388.

Zomer AWM, van den Berg B, Jansen GA, Wanders RJA, Tien Poll-The B \& van der Saag PT (2000) Pristanic acid and phytanic acid: naturally occurring ligands for the nuclear receptor peroxisome proliferator activated receptoro. Journal of Lipid Research 41, 1801-1807. 